$\begin{array}{ll} & \text { Etnográfica } \\ \text { etnográfica } & \text { Revista do Centro em Rede de Investigação em }\end{array}$

Antropologia

vol. 11 (2) | 2007

Vol. $11(2)$

\title{
Política do corpo e política de vida: a tatuagem e o body piercing como expressão corporal de uma ética da dissidência
}

Politics of the body, politics of life: tattoos and body piercing as a corporal expression of an ethics of dissidence

\section{Vitor Sérgio Ferreira}

\section{(2) OpenEdition}

\section{Journals}

\section{Edição electrónica}

URL: https://journals.openedition.org/etnografica/1979

DOI: 10.4000/etnografica.1979

ISSN: 2182-2891

\section{Editora}

Centro em Rede de Investigação em Antropologia

\section{Edição impressa}

Data de publição: 1 novembro 2007

Paginação: 291-326

ISBN: 0873-6561; E-ISBN 2182-2891

ISSN: 0873-6561

\section{Refêrencia eletrónica}

Vitor Sérgio Ferreira, «Política do corpo e política de vida: a tatuagem e o body piercing como expressão corporal de uma ética da dissidência», Etnográfica [Online], vol. 11 (2) | 2007, posto online no dia 26 setembro 2012, consultado o 10 fevereiro 2022. URL: http://journals.openedition.org/ etnografica/1979; DOI: https://doi.org/10.4000/etnografica.1979

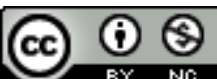

Etnográfica is licensed under a Creative Commons Attribution-NonCommercial 4.0 International License. 


\title{
Política do corpo e política de vida: a tatuagem e o body piercing como expressão corporal de uma ética da dissidência
}

\section{Vitor Sérgio Ferreira}

\begin{abstract}
A estética da divergência, que caracteriza a corporeidade extensivamente marcada com recurso à tatuagem e ao body piercing, configura uma forma de demarcação estilística através da qual alguns jovens constroem e dão a (re)conhecer não só a sua identidade pessoal, mas também o modo como percebem e se relacionam com o mundo. Implica uma performance estética que excorpora uma homóloga atitude ética, consubstanciando um sentido de desafiliação perante a ordem cultural e social estabelecida. Trata-se de uma ética de dissidência que reclama uma remoralização da vida quotidiana no sentido de conquistar um espaço social de existência no mundo, onde seja possível viver o compromisso com um corpo, uma identidade e um estilo de vida que se pretende «alternativo» aos disponibilizados pelo actual «supermercado de estilos», em condições de autenticidade, respeito e liberdade individual.
\end{abstract}

PALAVRAS-CHAVE: corpo, marcas corporais, jovens, política de vida, cidadania cultural.

\section{O CORPO COMO OPERADOR SOCIAL}

A incorporação tem surgido como conceito-chave na tradição sociológica a propósito do corpo, dando conta do processo corporal de «interiorização não verbal, inconsciente, mimética, automática, de certas disposições de desigualdade e de poder; mas não só como interiorização - também como reprodutor dessas realidades, seu confirmador constante pelo simples facto de estar lá, de aparecer, de ser» (Vale de Almeida 2004: 30). Nesta linha, a corporeidade tem sido tratada como lugar de inscrição simbólica, lugar sígnico que reflecte posições sociais na estrutura de relações de poder (que podem ser de classe, de género, 
de "raça", etc.). Enquanto fenómeno incorporado, o social deixa de ser da ordem da abstracção, para corresponder ao "implícito expresso pelo corpo no decorrer interactivo da acção (...) através do qual se autoconstrói e se automantém a vida social" (Drulhe 1987: 6).

O corpo assume assim o estatuto de operador social, onde o social se torna possível e onde, consequentemente, se revela a eficácia do social sobre o indivíduo. Esta visão estrutural pressupõe a incorporação como duplo movimento de interiorização da exterioridade (isto é, das condições objectivas de existência do agente incorporado) e de exteriorização da interioridade (sob a forma de percepções, representações, esquemas de classificação da realidade e práticas por parte do agente incorporado). Pressente-se aqui uma incarnação sobressocializada, "investindo na prática princípios organizadores socialmente construídos e adquiridos no decorrer de uma experiência social situada e datada" (Bourdieu 1998: 120).

Embora Bourdieu conceda ao corpo um estatuto epistemológico fundamental, enquanto forma do agente social "ser e estar no mundo, no sentido de pertencer ao mundo", esse estatuto pressupõe uma relação de posse do corpo por parte do mundo (social), "relação onde nem o agente nem o objecto são colocados enquanto tais" (Bourdieu 1977: 51). O corpo fica-se como operador através do qual o sujeito apreende o social e reproduz a ordem do mundo, lugar de naturalização do arbitrário cultural e social. Desta feita, acaba por ser "a este nível micro, quase imperceptível, da incorporação dos esquemas de diferença e de desigualdade, que se joga uma política de baixa intensidade, uma política de difícil intervenção por parte da usual macropolítica. É a política do face a face, do encontro casual de rua, da visibilidade confirmadora do que nos rodeia" (Vale de Almeida 2004: 30).

O corpo permanece, nesta perspectiva, "aprisionado pela circularidade da incorporação socialmente determinada. Corpo domesticado, de certa forma" (Lopes 2002: 61). Mas ele pode também ser (inter)subjectivamente vivido e agenciado - e, por consequência, analiticamente construído - como lugar de oposição, resistência e emancipação social, nomeadamente quando o indivíduo investe na sua realidade corpórea regimes ${ }^{1}$ imagéticos e cinéticos que tentam desafiar a ordem corporal e social existente. Daí que, em termos conceptuais, a mobilização social do corpo não deva ser reduzida aos mecanismos que operam no sentido da sua sujeição e contenção. O corpo também é passível de ser socialmente apropriado enquanto instância de contrapoder, na medida em que nele também há lugar à reacção.

l Utilizamos aqui o conceito de regime corporal na acepção de Giddens, a qual se refere aos comportamentos regulares que implicam o controlo sobre as necessidades orgânicas e os hábitos pessoais de autodisciplina corporal que, organizados e regulados de acordo com determinadas convenções socioculturais e estratégias de produção identitária, sejam relevantes para a continuidade ou promoção de traços corporais de ordem performativa ou imagética (1997 [1991]: 58). 
O lugar corporal, enquanto espaço que delimita e permite o reconhecimento do sujeito no mundo, não pode, portanto, ser olhado apenas como espaço de incorporação, ou seja, espaço de reprodução "natural(lizada)" de disciplinas e normatividades produzidas por saberes e poderes de natureza institucional ou informal. O poder que microfisicamente impregna o corpo, também designado de biopoder, ${ }^{2}$ tanto pode manifestar-se em acções socialmente constrangidas, como em acções socialmente libertárias, potencialmente produtoras de efeitos transformadores. O corpo tem sempre, em potência, essa dupla capacidade de se revelar lugar de conformação e confrontação social, de controlo e resistência, de autoridade e subversão, de contenção e excesso, de disciplina e transgressão, de poder e evasão, de alinhamento e oposição, de reprodução e inovação, de dominação e agenciamento, de subordinação e emancipação.

A análise das dimensões de exercício do biopoder não implica apenas, assim, tomar em consideração os dispositivos de vigilância, disciplina e dominação que integra. Importa também, cada vez mais, fazer sair da clandestinidade os dispositivos através dos quais os corpos subvertem a ordem que pretende programá-los (Cruz 2002: 163). Se a análise dos processos de incorporação tem proporcionado um conhecimento profundo sobre a forma como os mecanismos de docilização e a reprodução social actuam através do corpo, vale a pena agora olhar mais atentamente para as suas dinâmicas de excorporação.

Estas correspondem a práticas de exibição e ostentação pública do corpo, que materializam investimentos expressivos decorrentes de opções e decisões do sujeito, conscientemente ponderadas e planeadas, relativamente aos usos que faz do corpo. São manifestações que, dada a sua natureza intencional, voluntária e altamente reflexiva, denotam actos de vontade individuais - que não deixam, porém, de ser socialmente contextualizados. A performatividade e a agência implicada na mobilização dessas práticas permitirá assim, através da sua análise, encontrar mecanismos e estratégias de reacção e inovação social ancorados no corpo.

Olhar para a corporeidade pela óptica da excorporação, implica tomar o corpo na sua condição expressiva (Crossley 1997; Polhemus e Benthall 1975; Radley 1998). Uma condição, porém, que não se vê reduzida à simbolização decorrente de processos de categorização, incorporada por via da atribuição de signos por parte de outrem ao corpo do próprio. Enquanto lugar de mediação simbólica, no corpo justapõe-se um mundo de significados muitas vezes contraditórios entre si, onde as codificações investidas pelo agente incarnado (gramática de produção corporal) se podem observar resistentes às codificações exteriores (gramática de recepção corporal), mesmo que maioritárias e

2 Ou seja, a capacidade de agir sobre o corpo de outrem e/ou sobre o corpo do próprio, com o objectivo de o submeter a uma disciplina de optimização das suas capacidades e utilidades (Foucault 1979). 
tacitamente aceites. Enquanto meio de expressão excorporada, o corpo é lugar de simbolização subjectivamente intentada e gerida pelo próprio agente incarnado, considerando não apenas os sentidos por ele investidos sobre atributos físicos já possuídos (fenotípicos), mas também sobre atributos posteriormente acrescentados (diacríticos).

A condição expressiva da incarnação, acrescente-se, transcende as fronteiras propriamente físicas do self, na medida em que evoca fronteiras identitárias e de estilos de vida que remetem para certos "mundos sociais" específicos. A estilização excorporada pelo corpo corresponde, portanto, a uma estilização da vida, convoca simbolicamente um "mundo social" que contextualiza certa forma de ser, em consonância ou dissonância, conforme o corpo é usado para aderir às normas da corporeidade modal $^{3}$ e respectiva variação, ou para recusar ou distorcer os atributos carnais que definem os grupos sociais, através da apropriação de morfologias não normativas, formas expressivas de resistência corporal que tentam escapar às estruturas dos códigos morais que tendem a dominar sobre os corpos numa dada cultura somática (Boltantsky 1975).

\section{CORPOS ENTRE-VISTOS}

O corpo extensivamente tatuado e perfurado é tomado, neste artigo, como um caso exemplar de excorporação, ou seja, de expressão de um regime corporal reflexivamente projectado pelos respectivos portadores, resultante de uma cadeia de actos de vontade, onde se denota uma intenção de subversão face à corporeidade modal. ${ }^{4}$ Em termos metodológicos, a informação aqui apresentada e analisada conta, sobretudo, com relatos obtidos em situação de entrevista, semiestruturada na sua preparação, e semidirectiva na sua aplicação (Ghiglione e Matalon 1978: 57-58; Colognese e Melo 1998: 144; Ruquoy (1997 [1995]: 87).

Foram efectuadas quinze entrevistas individuais em profundidade, de natureza biográfica, a portadores de corpos extensivamente marcados, multitatuados e multiperfurados, profissionais ou apenas consumidores de tatuagem e/ou body piercing. Oito dessas entrevistas foram efectuadas em duas sessões distintas, dada a longa duração média de cada uma, que oscilou entre o mínimo de cerca de três horas e meia e o máximo de seis horas. Preferiu-se, portanto, menos unidades observáveis, mas susceptíveis de encapsular uma maior densidade de informação, a observações mais numerosas mas susceptíveis de produzir materiais relativamente mais pobres em termos da densidade simbólica e biográfica

3 A corporeidade modal corresponde a um determinado conjunto de traços corporais valorizados numa dada formação social (Berthelot 1983: 128).

4 Este artigo reproduz em parte as conclusões da tese de doutoramento do autor, nomeadamente as que respeitam à problemática da política do corpo marcado, devendo o leitor interessado em aprofundar o tema consultar o respectivo trabalho na íntegra. Ver Ferreira (2006a). 
captada. Em vez de se amplificar a homogeneidade do conjunto de entrevistados, e de apostar na "multiplicação excessiva do idêntico", preferiu-se a "escolha intencional de diversidades típicas", "estrategicamente recolhidas e tratadas em profundidade": "uma colecção de materiais, ainda que restrita, pode proporcionar a sua 'saturação' antes até de estar materialmente esgotada; o seu 'resto' será então um 'luxo para verificação”" (Hiernaux 1997 [1995]: $172,174)$, com o qual, na maior parte das vezes, os tempos e os orçamentos disponíveis para projectos de investigação não se compadecem.

Os entrevistados foram recrutados em estúdios de tatuagem e body piercing de Lisboa e arredores, sem nunca utilizar o tradicional método de "bola de neve" entre entrevistados, por forma a evitar efeitos de homogeneização da amostra em decorrência da dependência de redes de sociabilidade previamente estabelecidas. O processo de selecção dos entrevistados não foi aleatório, ou tão-somente resultante das conveniências, constrangimentos e facilidades pragmáticas do investigador no acesso ao universo observável, como muitas vezes acontece no uso de técnicas qualitativas (Payne e Williams 2005: 308). Enquanto amostra estratégica e intencional, conceptualmente conduzida e tipologicamente relevante, ${ }^{5}$ a selecção dos indivíduos entrevistados foi submetida a intenções explícitas.

Entre estas foi considerada, em primeiro lugar, a sua exemplaridade em termos do objecto de estudo (Ruquoy 1997 [1995]: 103), enquanto portadores visíveis de projectos extensivos de tatuagem e body piercing, tomando a extensão e a visibilidade das suas marcas corporais como critérios indicativos do grau de "radicalidade" do projecto corporal. Fez-se também por diversificar a amostra de casos entrevistados em termos de variáveis sociodemográficas clássicas, geralmente utilizadas em estudos extensivos, como o género, grau de instrução, origem social, condição perante o trabalho, mas também uma outra variável estratégica (Ruquoy (1997 [1995]: 104), relativa à pertença desses indivíduos a diferentes grupos de estilo. ${ }^{6}$

Trata-se, evidentemente, de uma amostra cuja representatividade é válida mais de um ponto de vista da pertinência e conveniência sociológica dos casos seleccionados (considerando alguns princípios socioestruturais tipicamente indutores de variação comportamental e representacional), do que pela significância estatística dos casos acumulados, resultando da "saturação dos casos que repetem a mesma estrutura de um determinado fenómeno, que não é do foro psicológico, mas releva do universo social" (Lalanda 1998: 878). A intencionalidade que presidiu à sua construção, mais do que medir e determinar quantitativamente

5 Ou seja, uma amostra que vale mais pela profundidade analítica que possibilita sobre o universo observado, do que pela sua profundidade morfológica, considerando o nível de descrição e generalização que permitirá (Pais 2001: 110). Glaser e Strauss (1967) chamaram-lhe theoretical sample.

6 Entrevistaram-se indivíduos que, durante a sua trajectória, se identificam ou já se identificaram no passado com grupos de estilo motard/byker, rock'a'billy, heavy metal, black metal, punk, skinhead, gótico, hard-core, straight edge e techno. 
proporções, prevalências ou probabilidades generalizáveis sobre os factores que influem na experiência social das marcas (Lieberson 1992: 106-109), foi a de aceder à identificação e compreensão das estruturas de sentido reivindicadas e atribuídas a corpos extensivamente marcados, assim como às formas como estas foram sendo socialmente produzidas nas biografias dos seus portadores. Partilhando da postura de Pais, entre outros autores, ${ }^{7}$ "ao estudar-se um caso, o objectivo não é representar o mundo; basta a representação do caso. Aliás, um caso não pode representar o mundo, embora possa representar um mundo no qual muitos casos semelhantes acabam por se reflectir" (2001: 109).

Considerando esse objectivo, o número de entrevistas formalmente efectuadas revelou-se suficiente para reconhecer a variabilidade de perspectivas e de significados construídos por parte de quem tem o corpo extensivamente marcado, que, para todos os efeitos, não se vislumbrou muito distinta. O efeito de saturação da informação (Bertaux 1997; Hiernaux 1997 [1995]: 173) foi denotado quando se observou que os entrevistados, com recrutamentos, trajectórias e condições sociais muito diferenciadas, e não mantendo qualquer relação entre si (ou seja, não constituindo um "grupo social" estruturado em torno de interconhecimentos e sociabilidades), recorrentemente produziam um discurso muito coerente e homogéneo, invocando quadros simbólicos muito semelhantes a propósito dos usos, sentidos e efeitos sociais de um corpo extensivamente marcado. Ou seja, quando a partir dos seus discursos começou a denotar-se a existência de uma narrativa sociologicamente convergente no sentido de uma certa estrutura de sentidos e contextos de produção (Abbott 1992: 69).

Além disso, o universo sujeito à observação e análise mais sistemática centrase num universo social ultraminoritário, que consubstancia um caso estatisticamente raro, atípico e marginal, reflectindo quadros simbólicos e modos de vida de um "núcleo duro" de indivíduos que, depois de terem experimentado, continuam a tatuar e a perfurar o seu corpo em larga extensão. É diferente do caso dos jovens que, em maior número, se limitam a tatuar um pequeno apontamento numa zona relativamente discreta do corpo, ou a colocar um ou outro piercing num dos lugares já socialmente legitimados e consagrados para a perfuração. As intenções invocadas, as significações investidas, os próprios recrutamentos e efeitos sociais decorrentes do uso dos mesmos recursos por uns e por outros, mas em quantidades diferentes, são substancialmente diferentes (Ferreira 2004c).

Parte desta amostra (cinco casos) é constituída por "profissionais" dedicados à prática da tatuagem (um) e do body piercing (restantes quatro), com graus de envolvimento e de dependência profissional muito diferenciados. São casos exemplares que acabam por não enviesar (biased) a amostra, na medida em que a sua condição profissional resulta sempre de uma condição prévia de consumidor durável desses recursos (Ferreira 2006b), sendo esta o mote principal das 
respectivas narrativas. Embora alguns desses profissionais estejam integrados em escalões etários dificilmente conotados com a "condição juvenil", havendo sido inicialmente solicitados sobretudo na condição de informante privilegiado, cedo nos apercebemos da riqueza biográfica dos seus trajectos de vida, nomeadamente da sua vivência enquanto jovens. A par disso, as suas trajectórias são exemplares do modo como este tipo de corpos se traduz em modos de vida relativamente estabilizados, indo bastante além da mera manifestação corporal de uma certa "irreverência" tradicionalmente atribuída à fase juvenil do ciclo de vida. Daí termos privilegiado os seus relatos a par dos relatos dos seus clientes, independentemente da idade que apresentavam.

O conteúdo discursivo das entrevistas, justificação única das mesmas, sem a qual o encontro não teria razão de ser, foi integralmente gravado, transcrito (por colaboradores) e validado (pelo investigador). Posteriormente à transcrição e validação dos discursos obtidos através das entrevistas, estes foram sujeitos a procedimentos analíticos dos respectivos conteúdos, segundo uma lógica de análise qualitativa (Maroy 1997 [1995]: 1 17), no sentido de estilhaçar, de desatar (Pais 1993: 86; 2001: 125; 2002: 150) as unidades de sentido expressas e encadeadas pelo actor social, e de voltar a unificá-las, a atá-las de uma forma analítica e sociologicamente conceptualizada. Isto na medida em que as estruturas de sentidos subjacentes ao material discursivo recolhido não têm que seguir, inevitavelmente, a ordem de inteligibilidades imposta pelo entrevistado. A ilusão da transparência dos discursos dos indivíduos sobre eles próprios (Bourdieu 1968), ou seja, a crença de que os entrevistados têm a capacidade de conhecer e reproduzir as condições relativas à sua acção, é uma tentação em que é fácil cair, quando, de facto, o que os actores testemunham sobre as suas práticas, acções e trajectórias não são mais do que as suas próprias representações e valorações sobre as mesmas, lógicas simbólicas em grande medida socialmente produzidas, inconscientemente inculcadas, que muitas vezes escapam à sua reflexividade e narratividade imediata.

\section{MARCAR O CORPO COMO ACTO DE REBELDIA}

A corporeidade extensivamente marcada com recurso à tatuagem e ao body piercing configura um projecto de corpo que, na linha da sua tradição histórica no Ocidente, continua a ser activamente apropriado como regime corporal não alinhado, resultante de uma cadeia de gestos simbólicos de irreverência e transgressão perante determinadas esferas de controlo social e de relações de poder. A parca minoria de jovens que, em Portugal, mobiliza actualmente projectos extensivos de marcação corporal, ${ }^{8}$ persiste em produzir e reproduzir

8 Menos de $1 \%$ da população entre 15 e 29 anos, considerando os jovens que afirmam já ter feito mais de uma tatuagem ou colocado mais de um piercing. Ver Ferreira (2003: 323). 
entendimentos sobre as marcas como manifestação de uma estética da divergência e uma ética da dissidência, expressão incarnada de estilos de vida que se pretendem escapatórios (Pais 2001: 71) à massificação e normativização vislumbrada nos estilos de vida dominantes, ${ }^{9}$ olhados como vias prescritivas e saturadas de viver e estilizar a vida.

A estética cultivada pelos usuários de corpos extensivamente marcados, orientada por valores de originalidade e pelo culto do neobarroquismo e do bizarro, confronta e interpela a estética "naturalista" hegemonicamente produzida e reproduzida pelos mecanismos dominantes de poder e de regulação corporal. Simultaneamente, desafia a ética dominante que disciplina o corpo contemporâneo, e que valoriza a maleabilidade e a abertura deste a recursos pautados pela efemeridade e pela superficialidade na carne, em contraste com a permanência e a invasividade que caracterizam os projectos de marcação corporal (Ferreira 2004b).

É nesta perspectiva que o acto de marcar a pele, quando empreendido em contextos juvenis, é descrito nas narrativas dos jovens entrevistados como decorrente de um traço de personalidade com que se identificam e que lhes é socialmente reconhecido, a rebeldia. Fazer uma tatuagem ou colocar um piercing começa por configurar um acto de rebeldia ${ }^{10}$ perante as normatividades que (pre)tendem prescrever e estandardizar a imagem corporal do juvenil e, em última instância, perante as convenções que informam a sacralização de um corpo "natural(izado)". Em simultâneo, assume a forma de desafio perante as instâncias que personificam social e institucionalmente o exercício de autoridade sobre os corpos e as biografias juvenis, representadas pelos pais, agentes educativos e/ou empregadores.

Eu era um bocado maluca e rebelde... (...) Eu nunca pude furar as orelhas. E eu acho que a resposta - e eu às vezes digo isto a gozar, mas acho que é a sério - foi, eu mal fiz 18 anos furei as orelhas todas! Aliás, porque eu estive 18 anos à espera para poder furar as orelhas, e então quando furei, eu costumo dizer se não me tivessem proibido, se calhar não tinha caído neste

9 "Um estilo de vida pode definir-se como conjunto de práticas através das quais os indivíduos se esforçam por estilizar a sua vida, isto é, fazendo corresponder diferentes aspectos da sua vida (alimentação, vestuário, habitação, etc.) com modelos que não emanam necessariamente da cultura 'dominante' ou da sua própria cultura" (Pais 1998: 23).

10 Há que distinguir os actos de rebeldia das práticas de resistência perante as relações de poder, os fundamentos do controlo social e as figuras da autoridade. Os primeiros, situados num tempo e num espaço restritos, correspondem a acções pontuais e mais ou menos impulsivas, sem qualquer tipo de reflexividade transformadora associada, muitas vezes discutidas por referência aos jovens como condutas características da sua idade e naturalizadas como fazendo parte do seu processo de crescimento e de autonomização. Em contraste com os actos de rebeldia, as práticas de resistência pressupõem acções dotadas de alguma intencionalidade transformadora, uma consciência oposicional que procura romper ou ganhar posição no que o actor percebe serem as relações de poder, sendo preconizadas com consciência dos efeitos pessoais e sociais que delas podem advir. Ver, entre outros, Raby (2005); Giroux (1992). 
exagero, não é? Assim como as tatuagens, pronto, nunca... Foi uma coisa sempre odiada e repudiada no meio da minha família e tudo. E eu, como acho que se calhar tenho um bocadinho a tendência, ou dantes tinha mais do que agora - essas coisas também desaparecem com as idades -, sempre tive um bocado a tendência a ser do contra e a ser diferente, então acho que caí nesse exagero precisamente porque nunca tive muita liberdade para fazer estas coisas. (Profissional de body piercing, 9. ${ }^{\circ}$ ano de escolaridade, sexo feminino, 34 anos)

... Sempre me viram como um gajo esquisito, cheio de brincos, com um cabelo esquisito, com roupas esquisitas, participava nestas coisas, andava à porrada, chegava a casa todo negro. (...) Mesmo mudando um bocado de estilos, eram sempre coisas rebeldes, porque eu sempre tive esse lado rebelde, (...) de ser contra as coisas que a sociedade quer. (Fiel de armazém, 8. ${ }^{\circ}$ ano de escolaridade, sexo masculino, 23 anos)

A incarnação de tatuagens e body piercing em larga extensão estilhaça, efectivamente, os códigos que fundamentam a "natural(izada)" discrição do corpo. Este sai da relativa indiferença a que está quotidianamente acantonado, e manifesta-se através de um tipo de ornamentação pouco habitual, inusitada, historicamente exotizada e sob suspeita (Ferreira 2004a; Peixoto 1990; Rocha 1985; Steward 1990). Quando as marcas são publicamente ostentadas, captam a atenção do Outro, atraído pela ruptura com os absolutos naturalistas que, hegemonicamente, dominam as actuais construções sociais do corpo ocidental e constituem a sua referência normativa.

Em virtude da sua divergência estética, as marcas continuam a apelar ao olhar e a deter a capacidade simbólica de desconcertar (Hebdige 1988: 18), obrigando os que com elas se cruzam a realizar a diferença entre o corpo que se vê e o que seria esperado ver. Na distância entre o corpo marcado e o corpo "natural(izado)" é criado um espaço de confronto simbólico que força o Outro a reconhecer e a tomar posição perante o corpo que vê, no sentido de reavaliar ou rejeitar o modelo de corporeidade com que se depara. Nesse espaço, os projectos de marcação corporal, ao salientarem a relatividade e a arbitrariedade do corpo "natural(lizado)", padronizado segundo as convenções de aparência ocidentais, são objectivamente investidos de um poder disruptivo dos ordenamentos semióticos e morais sobre o carnal (Hardin 1999: 91).

É esse poder disruptivo que fundamenta o valor de choque social das marcas corporais, o qual será tanto mais elevado quanto maior for a distância entre as "gramáticas de produção" e as "gramáticas de recepção" (Véron s/d) que, numa espécie de "guerrilha semiótica" (Hebdige 1986 [1979]: 17-18), se confrontam perante o mesmo corpo. Ou seja, num plano estritamente semiótico, quanto maior for o desajustamento entre os códigos investidos no projecto 
de marcação corporal por parte de quem o promove, e os códigos de leitura e interpretação que presidem à sua percepção exterior.

Eu geralmente nunca tenho muita tendência a fazer o que os outros fazem... Não é por contradição, percebes? (...) [usar piercing e tatuagem] Não me aflige absolutamente nada, independentemente da sociedade me criticar, ou de lhes repugnar - porque lhes repugna, embora esteja melhor agora - porque eles acham que... E se calhar isso também me dá um certo gozo, um certo desafio, percebes? Porque também acho que é um bocado aquela do espírito guerreiro que eu tenho. Acho que me dá um certo desafio, percebes? (...) Além de ser um grande acto de coragem tu usares piercings na cara e ires remar contra a maré... (Gerente de estúdio de tatuagem e body piercing, $9 .^{\circ}$ ano de escolaridade, sexo feminino, 39 anos)

[A primeira tatuagem feita por um profissional foi...] Um logótipo especial, e numa zona muito visível, que era aqui na cabeça, bem à vista de toda a gente. Na altura, havia muito pouca gente a ter ou a ostentar tatuagens cá em Portugal. Muito menos numa zona como a cabeça, que era de choque para toda a gente. Foi mesmo choque! E a ideia era mesmo essa, de chocar! E consegui, conseguir chocar toda a gente! A partir daí, nos anos seguintes, fiz mais e mais tatuagens, e... (...) [Fi-lo pel'...] A procura da diferença, sim. E depois o prazer que advém de a pessoa poder ver e aguentar o choque social que advém de usar algo que é "condenado" por quase toda a gente. (...) Eu, como qualquer adolescente, limitava-me a fazer o oposto daquilo que me era aconselhado. Vá lá, não imposto, nem obrigado, mas normalmente, como parte dos adolescentes rebeldes sem causa fazem, é ir contra àquilo que lhes é sugerido, ou proposto, ou imposto, seja lá o que for. (Profissional de body piercing, frequência universitária, sexo masculino, 25 anos)

A experiência vivida pelos jovens entrevistados demonstra como, apesar da crescente - ainda que reduzida - difusão e legitimidade social da tatuagem e body piercing (Ferreira 2003; 2004a), a acção de marcar o corpo continua a ser investida, na sua gramática de produção, de uma aura de inconformismo, de um sentido de não-conformidade, de transgressão do espaço de possibilidades legítimas de utilização decorativa do corpo, de ruptura com as convenções somáticas e as autoridades que as exercem sobre o corpo juvenil.

Não obstante a progressiva visualização e familiaridade social com as práticas de marcação corporal, amplamente televisionadas e publicitadas - processo através do qual têm vindo a ser gradualmente licenciadas e toleradas, sobretudo nas suas versões corporalmente mais moderadas -, a sua vitalidade transgressiva não se tem perdido. Particularmente quando os objectos e tintas começam a colonizar largas extensões epidérmicas (Ferreira 2004c), projectos corporais dotados 
de propriedades simbólicas que insistem em validar o acto de marcar o corpo como prática oposicional (Benson 2000: 242), prática divergente (Brito 2002: 43) ou prática subversiva (Pitts 2003: 23), isto é, prática que se constrói a partir da discordância e desidentificação com os valores e códigos dominantes.

Numa sociedade de consumo que, sob a forma de ciclos efémeros, tende à padronização e estandardização dos visuais, e onde o corpo juvenil é objectificado como consumidor privilegiado de objectos efémeros e massificados, o corpo extensivamente marcado assume o estatuto não apenas de eixo estruturante da construção da diferença individual, como também, simultaneamente, de suporte plástico de resistência social. ${ }^{11}$ Através da marcação corporal extensiva, com recurso à tatuagem e body piercing, alguns jovens de ethos mais insurrecto encontram uma forma de se manifestar expressivamente contra a homogeneização massiva e opressiva da diferença e de confrontar as forças sociais que tentam estandardizar ou docilizar, para empregar uma expressão cara a Foucault (1999 [1975]), os corpos juvenis na sua imagem.

\section{MARCAR O CORPO COMO ACTO DE EMANCIPAÇÃO}

A pretensão desses jovens em resistir é literalmente incarnada com recurso a objectos e a técnicas seculares de inscrição corporal, cuja leitura social dominante está desde há longo tempo associada a traços estigmáticos de "marginalidade", "contestação", "agressividade", "loucura" e "mutilação" (Ferreira 2003: 336-338). A legitimidade desse acto de transgressão, estes jovens encontram-na não apenas na sua ancestralidade e universalidade, mas também, sobretudo, na convicção subjectiva de exercerem um direito incondicional de intervenção sobre o seu próprio corpo, o único e precioso bem capitalizável que sentem como verdadeiramente seu, sempre disponível à sua acção e com o qual sempre poderão contar.

Com efeito, muitas vezes materialmente despojados de outros capitais, num contexto vivencial marcado pela flexibilidade, instabilidade e precariedade de outras formas de propriedade, alguns jovens encontram no corpo um topos permanente de realização e expressão pessoal, dotado de um valor patrimonial e auto-referencial sem par na actual sociedade ocidental, susceptível de ser capitalizado sob múltiplas formas. Ao mesmo tempo que é apropriado como "espaço liso" (Deleuze 1980) propício a performances de resistência social, enquanto terreno expressivo de divergência e de confrontação do Outro, é também reclamado como suporte de manifestações de existência individual, no sentido de permitir expressar exercícios de reivindicação do poder de si próprio sobre si mesmo.

11 Não é de hoje a utilização da tatuagem como símbolo de resistência. Já em contextos prisionais esta prática traduzia uma forma de resistência do detido face à situação de sujeição e uniformização corporal decorrente da encarceração. Ver Cunha (1996); Demello (1993); Kent (1997); Schrader (2000). 
Neste contexto, a luta pela subjectividade (McDonald 1999), inerente à formulação de projectos de marcação corporal, traduz-se numa luta pela propriedade privada do património carnal. Pelo envolvimento íntimo e perene que mantém com o seu suporte, a inscrição de uma tatuagem ou de um piercing no corpo afirma-se como forma privilegiada e relativamente democratizada de exercício do direito sobre a propriedade do corpo. Numa época em que esta questão está na ordem do dia em debates vários, de natureza legal, ética e política, ${ }^{12} \mathrm{a}$ marcação invasiva e voluntária da epiderme concede a quem a empreende um profundo sentido de posse, representando um gesto instaurador da soberaneidade do jovem no processo de tomada de decisão sobre um património sobre o qual ele entende dispor do domínio absoluto e incondicional.

$\mathrm{O}$ acto de tatuar ou de perfurar o corpo tem efectivamente subjacente uma reivindicação do direito de intervir expressivamente de forma contrária às convenções estéticas e éticas dominantes, sobre um património que é tido pelo jovem como pessoal, inalienável e insubstituível. É nesse pressuposto que, muitas vezes, tal acto é agenciado à revelia do conhecimento ou das opiniões dos representantes da "sociedade de controlo" presentes nos quadros de interacção nucleares dos jovens (pais, professores, empregadores, etc.). Reclamando o corpo através da auto-intervenção voluntária, o projecto de marcação corporal restaura um sentido de autodeterminação do jovem sobre o seu corpo.

É nesta óptica que os contornos desse projecto surgem narrados pelos seus protagonistas como exclusivamente dependentes da sua deliberação, empenho e gosto pessoal, opções voluntárias e reflectidas de intervenção corporal, actos de vontade que se pretendem praticamente libertos de qualquer tipo de constrangimentos exteriores. ${ }^{13}$ Enquanto pequena transgressão socialmente consentida, o jovem, ao tatuar-se ou perfurar-se, tem a possibilidade de construir para si próprio uma fiç̧ão de conquista de poder sobre o seu próprio corpo, enquanto sujeito social autónomo nas suas acções e decisões individuais acerca deste, na base do que acredita ser o exercício de um direito fundamental de usufruto sobre um património que tem como sua propriedade privada, capitalizável sem restrições que não apenas as que são definidas por si mesmo.

12 A propósito de temas como a manipulação genética, a amputação genital feminina, a violência doméstica, a homossexualidade, a prostituição, a doação de órgãos e a recolha de produtos corporais, o aborto ou a eutanásia, entre muitos outros temas. Para uma discussão analítica sobre a história social dos direitos de propriedade, privacidade e intimidade corporal, ver, por exemplo, Fontenay (1972); Borrillo (1994); Richards (2001).

13 Enfatizamos o termo praticamente na medida em que, para os jovens menores de 18 anos, os tatuadores e body pierciers profissionais assumem entre si tacitamente a norma de não fazer intervenções sem o consentimento prévio e por escrito dos respectivos pais, ainda que em Portugal não exista regulamentação oficial que os obrigue a tal. 
O que é que tu tens teu? Vamos ver: compras um carro, pediste dinheiro ao banco ou a um concessionário, compraste uma casa pediste dinheiro ao banco, quiseste electrodomésticos, tens de pedir dinheiro ao banco, o que é que tu tens de teu? Não tens nada, não tens nada. Tens o corpo. Então, se tens o corpo, é a única coisa que tu podes usar e abusar e que é tua. E tu mexes e não pagas nada a ninguém, porque é teu e tu podes fazer dele o que quiseres. Eu acho que 'tamos numa sociedade em que não temos nada de nosso, temos que trabalhar p'a pagar tudo, percebes? O que é que temos nosso? O corpo! (...) Dá-lhes mais prazer [às pessoas], se calhar, gastar sete mil e quinhentos escudos num piercing do que comprar uma $t$-shirt, percebes? Porque é mais delas. (...) Eu sou capaz de ver um indivíduo todo queimado porque fez uma scarification, e, para mim, sou capaz de dizer "que horror, eu não era capaz de fazer isso! Que horror!" Epá, mas ele deve ter tido um motivo, o qual eu não me interessa, nem quero saber. Ele lá deve ter na cabeça dele, ele é livre de pensar aquilo que ele quiser! Eh pá, ele usa e abusa do seu corpo, e mais ninguém tem a ver com isso, percebes? (Gerente de estúdio de tatuagem e body piercing, $9 .^{\circ}$ ano de escolaridade, sexo feminino, 39 anos)

Eu é que sei o que é que aqui está. Isto está na minha pele, e à minha pele eu é que sei o que é que tenho de fazer dela. (...) Porque o corpo é nosso, nós fazemos dele o que quisermos, apesar de não ser nosso em todos os sítios. Mas, prontos, enquanto ele for nosso e pudermos fazer, acho que não devemos estar a fazer coisas iguais. (...) Há vários países em que o corpo não é nosso! Por exemplo, em Marrocos... (...) É mesmo assim! É mesmo uma "boca calada" que não pode dizer nada, porque não interessa a opinião dessa pessoa! Para os outros ela não existe na sociedade, é um parasita que anda ali. (Tatuador, $8 .^{\circ}$ ano de escolaridade, sexo masculino, 24 anos)

A marcação extensiva do corpo satisfaz, portanto, o exercício pleno desse direito de propriedade corporal, concedendo ao jovem um modo de governo do corpo relativamente fácil de agenciar, pela sua disponibilidade comercial. Adornar extensivamente o corpo com tatuagens e brincos implica um conjunto de acções que funcionam simbolicamente para quem as agencia como reivindicação de autoridade e liberdade de intervenção sobre a carne. Subjacente à sua intenção de produção, está um sentido de resgate da autonomia no controlo sobre um património que o jovem considera exclusivamente seu, relativamente às instâncias que, em vários domínios da vida social (familiar, educativo, profissional, religioso, médico, jurídico, mediático, etc.), estão institucionalmente autorizadas a exercer o poder de produzir e regular a figura e o gesto do corpo juvenil.

O desenvolvimento de um projecto extensivo de marcação corporal não traduz, porém, apenas a vontade do jovem de tomar para si a plena posse do seu corpo. Tal como é descrita pelos entrevistados, a experiência da marcação 
corporal revela-se imbuída de um sentimento de agenciamento ou de puissance, como lhe chamaria Maffesoli (2002 [1992]), sentimento esse manifesto pelo jovem quando realça a sua capacidade individual em decidir marcar o corpo em condições de liberdade e autodeterminação. Encarando o corpo não apenas como bem primeiro mas também como extensão visível de identidade pessoal, enquanto expressão idiossincrática e concreta do $e u$, o jovem, ao marcá-lo extensivamente, também demonstra metaforicamente o direito alargado à propriedade de si próprio, onde qualquer violação do que entende ser o pleno exercício dos seus direitos de autenticidade, diferença e singularidade, atinge o cerne do seu projecto de identidade e de vida.

Marcar extensivamente o corpo configura, assim, uma tomada de posse sobre a construção da sua identidade e biografia pessoal, celebrando de forma simbólica, perante si próprio e os outros, o poder de (auto)determinação e (auto)controlo sobre a sua própria acção - poder esse que o jovem sabe frágil e vulnerável perante os condicionamentos impostos por determinadas instituições sociais "guardiãs da normalidade" da corporeidade e modos de vida juvenis (Laé e Proth 2002: 5). É nesta perspectiva que, tal como Giddens aponta, o problema da posse do corpo nas sociedades da "modernidade tardia" convoca, entre outros, os problemas que se geram em torno da definição de "pessoa", devido ao duplo envolvimento de sistemas abstractos (medicina, religião, Estado) e de projectos reflexivos nas opções que os indivíduos tomam relativamente aos regimes corporais a adoptar (Giddens 1997 [1991]: 202).

[a minha primeira tatuagem...] É minha! Fui eu que a fiz. Fui eu que a escolhi. Fui eu que decidi que a queria fazer.(...) Eu ainda conheço muitos casos de pessoas que têm filhos em idades relativamente novas, que vão furar as orelhas às criancinhas numa ourivesaria, a criancinha não tem a mínima hipótese de dizer que não quer, que não lhe apetece, que não gosta, e estão a expor a criança a algo que pode ser prejudicial. (...) [As tatuagens] São minhas! Eu não posso exercer posse sobre alguém. Mas posso exercer posse sobre o meu corpo. O corpo é meu. (...) O corpo é só nosso. Apesar daquilo a que estamos condicionados, ou seja, pelo trabalho, pela sociedade em que vivemos - não podemos andar nus, temos as nossas condicionantes - mas aquilo que fazemos com o nosso corpo só a nós nos diz respeito. É encarar um pouco as coisas como a prostituição. A prostituição é o quê? É o vendermos o corpo. $\mathrm{O}$ corpo só pertence à mulher que o vende. E ninguém pode julgar o que ela faz ou não com o corpo. A mim tanto se me dá. Ninguém me poderá a mim querer dizer o que é que eu faço ou o que é que eu deixo de fazer com o meu corpo! É meu, acima de tudo! [o entrevistado é muito afirmativo, quase soletra silabicamente as frases que vai dizendo] Não é da minha mãe, não é do meu pai, que são os responsáveis por eu estar vivo. Eles muito menos são aqueles que poderão controlar o que eu faço ou não faço. 
Apenas eu, mais ninguém, pode dizer o que é que eu faço com o meu corpo! É isso que as pessoas têm que se aperceber. Muitas pessoas não fazem uma tatuagem ou não fazem um piercing pelo receio do que os outros poderão vir a dizer, ou quais as consequências. O corpo é um invólucro. Um invólucro que nós representamos durante o tempo todo que cá estamos. E que nós podemos utilizar como nós quisermos! Mais nada! (...) A pessoa quer fazer essa modificação porque acha que se vai sentir mais à vontade, ou que se vai sentir melhor com ela mesma, e ninguém está no direito de a impedir. Não tem que aceitar! Mas também não pode impedir! O corpo, lá está, é a última fronteira. Sobre o nosso corpo só nós é que sabemos, só nós é que decidimos, só nós é que temos a possibilidade de fazer ou não a alteração, conforme aquilo que pensamos. (...) São as minhas conquistas pessoais, sim senhora, elas servem como questão de afirmação, mas afirmação pessoal, não uma afirmação perante os outros, como forma de provar alguma coisa a alguém, a terceiros. São minhas! É meu! Eu é que sei! (...) Eu volto a insistir no aspecto de que isto [as marcas] são conquistas pessoais. As pessoas fazem, algumas por questão de afirmação. E não há melhor maneira de nos sentirmos bem connosco mesmo do que podermos, ou sermos os únicos a legislar sobre aquilo que somos nós. Ou pelo menos sobre o nosso invólucro. (Profissional de body piercing, frequência universitária, sexo masculino, 25 anos)

Enquanto acto potencialmente subversivo das convenções corporais dominantes, marcar o corpo configura um gesto de emancipação, isto é, uma acção que aponta para a reivindicação e conquista de uma margem de autonomia pessoal do jovem no processo de tomada de decisão sobre a construção de si próprio e da sua vida perante os pólos sociais de autoridade que a atravessam. Ao permitir restituir ao jovem um sentido de capacidade de agenciamento, a acção de marcar corpo "constrói uma ficção de liberdade e autonomia pessoal" que visa "o direito fundamental a usufruir dele [o corpo] como quisermos, enfatizando a sua possessão individual" (Ortega 2004: 255). Expressa a liberdade de tomar uma posição e decidir sobre o que entende ser uma propriedade "naturalmente" pessoal e intransmissível, mesmo que se reconheça o corpo como legado material dos pais. É neste sentido que, nos termos nativos, o acto de marcar o corpo toma a forma discursiva de "afirmação pessoal", confirmando o jovem na sua conquista de independência, e expressando-a socialmente através da sua ostentação pública.

\section{MARCAR O CORPO COMO ACTO DE DISSIDÊNCIA}

Tatuar-se ou perfurar-se, enquanto prática de resistência, reflecte tensões sociais e culturais mais amplas que as que tocam o corpo, manifestando uma atitude de distanciamento simbólico perante padrões dominantes na actual ordem 
social. Quando as tatuagens e piercings atingem uma larga extensão no corpo, o projecto de marcação corporal tende a implicar um processo de densificação do investimento simbólico (Ferreira 2004c), representando convicções, valores e representações que ultrapassam as fronteiras do corpo, e que tocam quer o modo como o jovem se define a si próprio, quer o modo como este se define perante a sociedade actual.

É nesta óptica que se encontram com bastante regularidade, na órbita dos núcleos sociais de produção e difusão das práticas de marcação corporal, inflamados discursos críticos dirigidos a formas de organização social e de relações de poder difusamente descritas como "sistema capitalista", "sociedade de consumo", "sociedade individualista" ou "sociedade tecnocrática", bem como aos valores que lhes associam: "materialismo", "consumismo", "narcisismo", "burocracia"... Mais do que as instituições que constituem essa entidade diluída que muitos destes jovens designam de "sistema" (o mercado, as instituições políticas, a família, as classes sociais, etc.), esses mesmos discursos atacam os processos sociais que resultam em convenções culturais e consensos sociais instalados ("massificação", "globalização", “individualização”, "desumanização", "consumismo", "tecnologização", "polarização social”, etc.), vividos como uma cultura mainstream que reduz a experiência pessoal e social a um produto da "comunidade" ou a um conjunto de mercadorias. ${ }^{14}$

Muitas vezes, as referências ideológicas que servem de base a esses discursos críticos servem igualmente, aos jovens que os enunciam, de mote iconográfico para signos a gravar na pele: símbolos nacionalistas, nacional-socialistas, punks, místicos, heréticos, etc. Utilizada como expressão de resistência a uma certa ordem social, a marcação extensiva do corpo acaba por ser apropriada como recurso que podemos designar de contra-modernidade: por um lado, é estrategicamente utilizada pelos seus agentes como forma de demarcação pessoal perante determinada noção de "vida em sociedade", vista sob a perspectiva darwinista da metáfora da "selva", onde ocorre uma constante "luta entre os mais fortes e os mais fracos", alheia às profundas consequências ecológicas e humanas que provoca; por outro, sendo um recurso culturalmente ancestral e universal, serve também como forma de demarcação simbólica face às actuais noções de "progresso" ou "desenvolvimento" operadas pela radicalização das formas sociais capitalistas, que, segundo estes jovens, elegem o sucesso económico, o consumismo e o individualismo mais narcisista como formas privilegiadas de realização pessoal, e premeiam a capacidade de adaptação do agente às contingências e exigências do sistema, interpretada como forma de "corrosão do carácter" (Sennett 1998).

14 Já Touraine advertia para o facto de a transformação do indivíduo em sujeito resultar da combinação de duas afirmações: nas suas palavras, "a do indivíduo contra a comunidade e a da convicção contra o mercado" (1995: 29-30). 
No pressuposto da imagem que constroem sobre a actual sociedade, o futuro que lhe vislumbram é nebuloso e visto com apreensão, característico de um cenário distópico que tende a oscilar entre uma visão de fatalismo apocalíptico, que aponta para uma imagem caótica do eclodir do mundo, e uma visão de niilismo céptico, onde é adoptada uma postura de suspensão e indeterminação perante o tempo vindouro. Perante um futuro olhado com pessimismo e incerteza, a construção e expressão das subjectividades destes jovens tende a ser projectada sobre o que têm como sendo o mais estável representante de si próprios - o corpo -, e focalizada nas solicitações e gratificações sensuais do tempo presente.

\section{FATALISMO APOCALÍPTICO}

O futuro é incerto, não sei... (...) Vai ser o caos, mesmo. Vai haver uma grande confusão. (...) Sei lá, isto vai acabar, isto é alta destruição, mais cedo ou mais tarde. (...) A cena está cada vez a tornar-se mais... bué esquisita. Acho que não vai ser assim muito positivo, honestamente. Mas quando digo o caos, a cena é que para mim a natureza em si ninguém manda nela, e ela acaba por se vingar, directa ou indirectamente. (Estudante universitário, sexo masculino, 20 anos)

Eu acho que isto vai rebentar. Sabes, eu há muitos anos vi uns desenhos animados que eram demais: era um velhinho que era do planeta Ómega. Pronto, a terra evoluiu, evoluiu, evoluiu, evoluiu, até que se chegou ao espaço. E um dia o homem virou-se contra tudo e contra todos, e voltou a cultivar p'a comer. E isso ficou-me de memória, esses desenhos animados... E penso muitas vezes que isso vai acontecer, sabes, isto vai chegar a um ponto vai estourar. (Gerente de estúdio de tatuagem e body piercing, $9 .^{\circ}$ ano de escolaridade, sexo feminino, 39 anos)

\section{NIILISMO CÉPTICO}

O futuro é levado dia a dia. Nem pessimismo, nem optimismo. Em certa parte, sou eu que faço o futuro, não é? Tentar que ele seja porreiro. (Profissional de body piercing, estudante universitário, sexo feminino, 27 anos)

Eu não gosto de fazer previsões acerca do futuro. Mas não prevejo assim nada de bom... Não! Não sou pessimista, sou... Como é que hei-de dizer?... Sou... agnóstico. Sou agnóstico. (Profissional de body piercing, frequência universitária, sexo masculino, 25 anos)

No prolongamento da atitude de distanciamento crítico perante a ordem social subjectivamente vivenciada, os jovens entrevistados revelam ainda um profundo sentimento de "distância ao poder" (Cabral 1997), expresso, por um lado, numa forte desconfiança perante o funcionamento do sistema político, as instituições e 
as pessoas que o representam, bem como, por outro, no desinteresse, ou mesmo na recusa, pela adesão a formas tradicionais e alinhadas de exercício da cidadania política, como sejam a participação eleitoral e/ou associativa. Manifestam, ainda, alguma dificuldade em se posicionar no espectro político-partidário português, bem como em lidar com a tradicional clivagem esquerda-direita, cada vez mais frágil enquanto pólo de identificação política e secundarizada em favor de novas formas de olhar e ordenar o político, o ideológico e os conflitos sociais (Beck 2000: 41). Aqueles que se posicionam, tendem a demonstrar alguma simpatia pelos "novos" pequenos partidos de esquerda (como o Bloco de Esquerda), portadores de uma agenda política mais próxima das preocupações e valores sociais característicos da cultura política desses jovens.

A saturação demonstrada por estes jovens perante a forma social e política estabelecida (Maffesoli 2002 [1992]): xiii), apresenta modulações atitudinais diversas, as quais tendem a ser geralmente interpretadas por observadores e analistas sociais como expressão de indiferença, resignação e inércia social. ${ }^{15}$ Sem pôr em causa a legitimidade do sistema democrático, estes jovens tendem a oscilar entre uma atitude de descontentamento (caracterizada pelo desencanto com o modo de funcionamento da democracia, das suas instituições e das autoridades concretas que as dirigem, bem como pela insatisfação com as formas de actuação dos governos e respectivos outputs políticos) e uma atitude de desafeição política (esta caracterizada por uma percepção de separação e desinteresse mútuos entre o mundo da política e os cidadãos, expressa numa síndroma de sentimentos partilhados por estes últimos relativamente ao primeiro, que passam pela alienação, desconfiança, cepticismo, fatalismo, hostilidade e impotência perante a ineficácia, irresponsabilidade e exploração que atribuem ao poder político). ${ }^{16}$

\section{ATITUDE DE DESCONTENTAMENTO}

Eu sempre fui um bocado dessa onda de rebeldia, tive sempre esse toque, sempre fui PSR, Bloco de Esquerda, e agora vou votar Bloco de Esquerda outra vez. Se tudo correr bem e se conseguir, até vou participar na campanha de eleição deles. Não sou comunista nem sou de extrema-direita, sou de extrema. (...) Se as pessoas parassem e pensassem um bocadinho, o que é o governo? Começa logo por aí, o que é que eles fazem? E depois surgem as comparações de governo para governo: o que é que uns fizeram e o que outros fazem? Quem é que é o mais sério? Porque numa campanha eleitoral,

15 Tal interpretação, contudo, só faz sentido se nos limitarmos a pensar a acção política nos termos em que esta é formatada na esfera política tradicional, seguindo o respectivo modelo universalista, macroscópico, normativo, burocrático, racional, contratual e vinculativo de representação, organização e intervenção social.

16 Padrão que, de resto, reproduz o modelo atitudinal dominante da população portuguesa perante o sistema político que a representa. Ver Magalhães (2004). 
o que eles fazem é tentar mostrar quem é o mais sério, que a gente acredite neles e não nos outros. (...) O PS, em meia dúzia de aninhos, já atribuiu mais de dez mil cargos. O Cavaco em dez anos, não estou a dizer que sou a favor dele, mas o Cavaco, em dez anos, atribuiu três mil. Este governo PS que ainda não chegou a cinco anos, em três anos deu dez mil cargos, ou seja dez mil parasitas a viverem à minha, à tua, à pala de todos os portugas. Mas os portugueses são tão inteligentes que não se preocupam com isso: "caga nisso, a gente anda de BM também!" O gajo que anda de Opel Corsa não interessa. É a mentalidade deste povo e esquecem-se que estão a gastar, a dar milhões a gajos que não fazem népia, só vivem às tuas custas e andam com um Audi, um BM, com aquelas grandes máquinas que eu provavelmente também gostaria de ter se tivesse dinheiro para as ter. (...) [O futuro é...] Negro. Não vamos por isso cair por terra, baixar a cabeça e deixar de acreditar seja no que for, há mais motivações. Por exemplo, para mim, eu vou buscá-la à vinda da pessoa que eu amo. Ela veio de Londres e não vai voltar para lá. Veio de vez. Lindo! Poderoso! Acho que isso é força suficiente para eu acreditar em mais do que em Nostradamus. (Fiel de armazém, 8. ${ }^{\circ}$ ano de escolaridade, sexo masculino, 23 anos)

\section{ATITUDE DE DESAFEIÇÃO}

Nem perco tempo a falar de políticas. Eu é que me tenho de safar. Eu e aqui em casa. Agora os outros estão mesmo em segundo plano. Não fui eu que fiz, vou ter mesmo é que me adaptar da melhor maneira possível. É assim que eu vejo, seja qual for o governo! Seja qual for... epá seja de direita ou de esquerda, pá eu ando aos sss. (...) Politicamente nem discuto. Sou apolítico, não tenho nada a ver com essas coisas. Não passo cartão. Nem sei se sou apolítico, tás a ver. É o que já me chamaram. Cada vez que me ouvem a falar de política, é o que me chamam é apolítico, mas se calhar nem isso sou, eu simplesmente nem falo. [Nunca votaste?] Não, nunca. Nunca na vida, nem me vou dar a esse trabalho. Epá, sou capaz de concordar com umas coisas de uns, com outras coisas de outros, mas não há nenhum que me faça: "eu voto, eu concordo contigo". Não! Uns podem ser muito bons numas coisas, darem muita coisa. Mas, se for preciso, já fazem outras que eu já não curto. (...) Sou a favor da democracia, mas nem lhe ligo. É assim: eu estou mesmo a cagar para a sociedade! Os meus valores são só naqueles que me rodeiam, aí é que eu gosto de ver a democracia. Quando há algum problema, então... Olha, tipo na banda. A democracia, onde costumo usar o termo, é na música. Por exemplo, um gajo faz uma música e há uns que não gostam. Então a gente vamos votar, a maioria decide e assim é que há o respeito, tás a ver. Assim é justo para todos. E se empatar vamos à sorte, também é justo, tás a ver? A democracia para mim, quando falo de democracia não é preciso ser logo a falar do país e de política. A democracia acho que tem de começar é em casa, 
se for preciso. Primeiro assim no grupo de amigos, só então é que... E como isso eu não vejo, por isso pouco me diz. Política para mim nem é conversa, eu acho que nem sei falar de política. A mim é só se me perguntarem o que é que achas bem e o que é que achas mal. (Electricista na construção civil, 8. ${ }^{\circ}$ ano de escolaridade, sexo masculino, 28 anos)

A dificuldade em lidar com os mecanismos e instituições representativas do modo tradicional de exercício da cidadania política característica da cultura política destes jovens, não implica, contudo, a sua alegada despolitização no sentido da inércia ou resignação passiva perante os actuais problemas sociais e políticos, ou no sentido da inexistência de reflexividade, discussão e empenhamento político. ${ }^{17}$ Pelo contrário, a atitude crítica que, descontentes e desafectos, assumem perante a acção e instituições políticas convencionais, indiciam uma forte consciência cívica por parte destes jovens, mesmo quando esta implica reacções de saída como resposta estratégica ao modo de funcionamento do sistema (Hirschman 1970). Saídas, designadamente, em direcção a espaços de socialidades alternativas (Maffesoli 2002 [1992]: 85) ou retiros subculturais (Rucht 1990: 162), que não deixam de ser animados por uma lógica de divergência reformista das fundações sociais, políticas morais, e de transformação das mesmas.

Se muitas vezes as novas gerações negligenciam e se mostram alienadas das agendas, das causas e das formas de acção política mais institucionalizadas, dos centros de poder e decisão tradicionais, em alguns desses jovens esse sentimento de alienação corresponde a uma postura consciente e cultivada, na medida em que pretendem justamente escapar a essa esfera de acção tradicional rumando em direcção a outras. A alienação é aqui entendida não no sentido marxista do termo, mas no sentido da partilha de um sentimento de alien dentro das sociedades modernas, ou seja, um sentimento de distanciamento crítico perante o mundo que os rodeia, percebido com desencanto e pessimismo, um sentimento de demarcação do sistema em que se vêem implicados, na sua ordem cultural, social e económica.

Alienar, do latim alienare, quer dizer tornar-se alheio, alhear-se, transferir para outrem o domínio de. Ora, é o que estes jovens fazem: alheiam-se do "mundo real" que conhecem, deixando o seu domínio ao cuidado (inglório, na sua perspectiva) dos políticos profissionais, e transferem-se para outros domínios sociais mais apetecíveis, sedutores, receptivos aos seus valores mais profundos e conectados com as suas experiências de vida, onde maneiras

17 Conjunto de atitudes e de comportamentos que os tradicionais autores da ciência política vêm a designar como "negligência política", no sentido do silêncio, inacção, abandono, redução de esforço e de atenção ao exercício político institucional e aos problemas sociais a que este acorre. Ver Magalhães (2004: 356-357). 
radicalmente diferentes de pensar, de ver e de ser no mundo podem ser experimentadas e desenvolvidas. Sempre assim foi, desde os boémios românticos do século XX.

Distantes do fusionismo organizativo, da planificação estratégica, da visão colectivista, bem como das práticas e das causas políticas ancoradas na real politik, alguns jovens encontraram nas microculturas ${ }^{18}$ que povoam o underground, espaços socialmente descomprometidos e informais, mais sociativos que associativos, onde com facilidade se podem hospedar em permanência ou temporariamente. São espaços que estes jovens sentem em conexão com a sua própria experiência vivida, sentindo-os também disponíveis à vivência da experimentação, exploração, descoberta, partilha, celebração e legitimação de práticas, emoções, reflexões, atitudes perante a vida e a sociedade, de uma forma criativa e inovadora.

Esses ensaios envolvem muitas vezes usos disruptivos das categorias de gosto e códigos de consumo dominante promovidos pelas indústrias culturais sobre determinados recursos expressivos, como a música, a escrita, o design gráfico e o próprio corpo. É nesta óptica que as microculturas juvenis oferecem o enquadramento para os jovens dramatizarem a sua própria corporeidade sob a égide da divergência, tentando visuais excêntricos e explorando os seus limites, providenciando os mecanismos sociais necessários para uma socialização inclusiva e legitimadora, com ganhos acrescidos de auto-estima e reconhecimento identitário no sentido da "individualidade" ("ser diferente"), "autenticidade" ("ser eu próprio") e "autonomia" ("ser livre”).

\section{A REFLEXIVIDADE TRANSFORMADORA DO ACTO DE MARCAR O CORPO}

As microculturas juvenis cresceram impressivamente em Portugal desde os anos 80 , num contexto de desencantamento com as instâncias políticas tradicionais seguido à euforia do período pós-revolucionário, de crescimento económico e consequente maior propensão ao consumo e ao lazer, de abertura cultural ao exterior, com a consequente democratização do espaço público e relativa liberalização dos costumes, de massificação e prolongamento da escolaridade

18 Dada a controvérsia mantida academicamente sobre a actual validade heurística dos conceitos de subcultura (que privilegia o eixo analítico do poder), contracultura (que privilegia o eixo analítico da ação), neo-tribo e cena (privilegia o eixo analítico da forma, da encenação imagética e/ou performática) no âmbito da sociologia e antropologia da juventude, opta-se neste trabalho por um termo conceptualmente mais "neutro" para designar este tipo de contextos e culturas juvenis de pequena escala, o de microculturas, no sentido de "fluxo de significados e valores manejados por pequenos grupos de jovens [e não só] na vida quotidiana, atendendo a situações locais concretas" (Feixa 1998: 270). Ao mesmo tempo, valoriza-se uma abordagem sobretudo émica dessas categorias, deixando que elas fluam dos discursos dos entrevistados, averiguando os respectivos conteúdos simbólicos. Para uma abordagem sobre os estudos pós-subculturais, ver Muggleton (2000 [2002]); Muggleton e Weinzierl (2003); Bennett e Kahn-Harris (2004); Hesmondhalgh (2005). 
obrigatória, que coloca os jovens numa situação de moratória de "integração cívica" e dependência parental mais prolongada. Neste contexto, as cenas ou ondas juvenis - com os seus valores, práticas e recursos estilísticos - tiveram oportunidade de difundir-se nas zonas urbanas do país, encontrando um lugar receptivo nos corpos e mentes de muitos jovens desafectados e/ou desencantados com os formatos mais ortodoxos de participar socialmente.

Objectivamente à margem dos centros de poder e dos processos institucionais de tomada de decisão, e não vendo neles representados os seus interesses e preocupações, alguns jovens encontram nesses espaços microculturais oportunidade de se fazerem representar socialmente como tal, configurando formas sociabilísticas especificamente juvenis de participação, socialização e protagonismo social, com linguagens e códigos próprios para se expressarem enquanto sujeitos de si próprios, para produzirem e manifestarem as suas opiniões e aspirações sobre o mundo (Blackman e France 2001; Blackman 2005). Aí eles deixam de constituir "vítimas" que necessitam de "cuidados intervencionistas" (como acontece nos espaços políticos tradicionais orientados para os jovens), ou meros agentes de consumo (como sucede no espaço das economias que têm os jovens como público-alvo), encontrando possibilidades concretas de participar socialmente no sentido de gerir e negociar os seus próprios interesses e expectativas.

São vários os autores que localizam o lugar cada vez mais privilegiado concedido ao corpo no âmbito desses "movimentos juvenis", através da potencialização expressiva das suas dimensões imagéticas e cinéticas. ${ }^{19}$ Socialmente encorajados (e responsabilizados) a gerir a sua forma e imagem física cada vez mais cedo, alguns jovens, nesses contextos sociais, têm oportunidade de tomar o corpo (a par de outros recursos expressivos como a música, por exemplo), como lugar de intervenção social e de protagonismo público, como lugar de exercício de cidadania, no sentido em que sobre ele mobilizam um conjunto de recursos e procedimentos que expressam assunções e reivindicações sociais, produtores de controversas discussões sobre direitos e responsabilidades pessoais (Ule e Rener 2001: 274).

O tipo de manifestações que operam sobre o corpo são mais praxeológicas que discursivas. Nas suas performances semióticas, motoras ou sensoriais, o corpo manifesta-se e torna-se ele próprio manifesto (Vale de Almeida 2004: 35). Um manifesto que se dá a ver mais que a fazer-se ouvir. Fragilizados no uso da "discursividade", pela dificuldade de acesso que têm aos canais da sua transmissão, estes jovens menosprezam o debate a favor do combate, a discussão

19 A este propósito ver, por exemplo, McKay (1996). Veja-se ainda a análise empreendida por McDonald $(2002 ; 2004)$ sobre os casos dos movimentos pró-anoréticos ou relativos à prática do chi kung. Sem que os trate aprofundadamente, o mesmo autor referencia ainda, a título da centralidade do lugar do corpo nestes contextos juvenis, a experiência da dança, das tatuagens e piercings e dos desportos radicais (2004: 586-589). 
em benefício da acção. As inscrições corporais tomam a forma de "palavra", tornando a pele numa proclamação silenciosa dos princípios que orientam a existência desses jovens. Muitos deles não só pintam e perfuram permanentemente o corpo, mas também não o alimentam através da ingestão de produtos de determinadas marcas ícones do sistema capitalista e da sociedade de consumo, ou tão-somente de carne e seus derivados, ou ainda não o cobrem com peles de animais, por exemplo. São actos que remetem para estratégias de boicote ao consumo, ou seja, onde o poder do cidadão enquanto potencial consumidor, na rejeição do uso de determinado bem ou serviço, é exercido no sentido da contestação às condições de produção, distribuição e/ou comercialização desses mesmos bens ou serviços. ${ }^{20}$

Em todos estes actos, o corpo é reflexivamente mobilizado e experimentado enquanto lugar quotidiano de exercício de autodeterminação e emancipação, onde se cruzam lógicas estéticas e éticas susceptíveis de curto-circuitar as convenções culturais dominantes, no sentido do respectivo alargamento e diversificação. Enquanto lugar de expressão pública de uma atitude de distanciamento simbólico e crítico sobre os ordenamentos sociais, bem como sobre o modo de fazer e de pensar tradicionalmente a acção política, o corpo, ao ser sucessivamente marcado, vem reflectir uma estratégia de confrontação social cada vez mais informada, consciente e reflexiva acerca dos potenciais efeitos transformadores decorrentes dessa mesma intervenção.

Apesar de poderem conter intenções e efeitos disruptivos, a reflexividade transformadora (Pais 2004: 20) subjacente a estes actos tende a ser pouco ambiciosa em termos de objectivos de mudança social. Não têm pretensões de dar voz a colectivos uniformes, consubstanciando intenções (que se pretendem) individualizadas, tendo como ambição transformadora uma escala que vai pouco mais além das intersubjectividades que densificam o mundo de vida do actor que as agencia (Raby 2005: 153-154). Sem perder o seu propósito contestatário, no sentido do agir em não-conformidade, são estratégias que tendem a assumir mais a forma de demarcação pessoal perante os modelos prescritivos da sociedade global(izada) do que de imposição colectiva de um dado modelo, enquanto tentativa de dominação por parte de um dado grupo no sentido de impor a todos os outros o seu modo legítimo de identificação. A sua reflexividade transformadora está mais direccionada para, através do desafio que advém da oposição e confronto, garantir um espaço social para a existência da sua diferença específica, dar a conhecer a diversidade de modelos de corporeidade alternativos e estilos de vida minoritários, desconstruir os estereótipos

20 Este tipo de acções manifesta a consciência de que o acto de consumo, enquanto forma de acção social, se encontra profundamente implicado na organização política e económica das relações de poder, permitindo criar uma ilusão de eficácia deliberativa e de participação activa na vida colectiva, embora ancorada no foro da vida privada. Ver Canclini (1995); Friedman (1999); Orlie (2002). 
que sobre estes recaem e, em última instância, tentar o seu reconhecimento social enquanto possibilidades legítimas de corpo e de vida.

Nesta perspectiva, a política que subjaz aos projectos de marcação corporal empreendidos por estes jovens não é propriamente revolucionária, no sentido de tentar substituir os modelos dominantes pelos seus próprios modelos. Não serão, portanto, expressão de práticas aniquilatórias, no sentido em que oferecem a possibilidade de mudar o mundo, enquanto estratégias de luta com o objectivo de destruir a "ordem social vigente" e impor uma nova ordem substitutiva, mas práticas predatórias, ou seja, práticas que aproveitam o espaço e os meios que a actual ordem social thes disponibiliza no sentido de se (a)firmarem e se fazerem reconhecer enquanto possibilidades alternativas, a par de outras, tentando deste modo expandir as fronteiras culturais da expressão e da criatividade pessoal (através do corpo, da indumentária, da música, da palavra, da imagem, etc.).

[A minha primeira tatuagem foi...] Uma tatuagem um pouco de índole política, que já na altura mostrava o meu desagrado pela forma como se orientava a sociedade. (...) No meu caso, [a marcação do corpo] foi precisamente o desafio de estar a trazer algo de novo e não é só usar por uma questão de afirmação. É também saber por que é que o estou a fazer, criar também uma antiestética, ou uma antimoda, e saber defender os meus pontos de vista. É utilizar, saber porque é que estou a utilizar, dar uma boa argumentação para aquilo que estou a fazer, e defender o meu ponto de vista perante os outros. E isso até agora consegui. Consegui fazer com que os outros aceitassem, apesar de poderem não concordar, tiveram mesmo que aceitar, no modus vivendi e modus operandi. (...) [As modificações no corpo...] No meu caso, em termos de intervenção política, não será bem, vá lá, a forma de passar uma mensagem. Será mais uma postura, o desprezo pelo estereótipo, mas será uma postura que contesta os valores impostos. Não é propriamente ir contra o estereótipo, mas negá-lo. Ou seja, é como afirmar “eu posso continuar a ser tão bom quanto os outros, sem querer aparentar como todos os outros o querem fazer". Ou seja, sem seguir o modelo existente. Lá está, o que é que acontece? Se muita gente adoptar a minha ideia, passa a ser esse o modelo existente. E então aí as coisas invertem-se e deixam de ter sentido. Nessa altura, já me vai ser impossível retirar as tatuagens todas, portanto, mantenho a minha filosofia, continuo a dizer que elas são as minhas, são as minhas conquistas pessoais, sim senhora, elas servem como questão de afirmação, mas afirmação pessoal, não uma afirmação perante os outros, como forma de provar alguma coisa a alguém, a terceiros. São minhas! É meu! Eu é que sei! (...) Talvez o que haja seja uma necessidade por parte das pessoas de se demarcarem desta sociedade dita moderna. Ao dizer "não estamos de acordo com isto, então procuramos outras maneiras de estar". (Profissional de body piercing, frequência universitária, sexo masculino, 25 anos) 
Denota-se, aliás, nos depoimentos, a existência de um sentimento comummente partilhado de impotência perante a hipótese de, colectivamente, mudar o Mundo, no sentido de qualquer modelo de organização social definido, demarcando-se da lógica de acção social de movimentos juvenis do passado. Essa intenção nem sequer é equacionada. Embora descontentes ou desafectos ao modelo social existente, não existe qualquer tipo de programa social estruturado por detrás dos gestos de que excorporam, no sentido de expressar um imaginário de "sociedade melhor" ou "sociedade ideal", com aspirações futuras de "igualdade", "harmonia" e "justiça", como acontece em grande parte dos programas sociais de natureza utópica.

Os jovens entrevistados não vêm, de facto, armados de novos artefactos sociais para tentar instituir colectivamente uma nova ordem social. Pelo contrário, há da sua parte uma recusa iconoclasta das maquetas sociais que denotem, à partida, tal ambição. Os programas sociais utópicos que alguns (re)conhecem (como a anarquia, o comunismo ou o nacional-socialismo, por exemplo) são, por vezes, invocados sob a forma de chavão, mas mais no argumentário crítico que proporcionam relativamente às recentes formas de organização social das sociedades ocidentais, que na dimensão prepositiva e programática que os seus manifestos tendem a prescrever para o futuro societário. Estes jovens denunciam mais que anunciam, diagnosticam mais do que prognosticam.

A sociedade ideal não existe. Não há nada ideal, para mim os ideais morreram há muito. (...) Creio em mim. Pronto. De resto, não creio assim em muito mais coisas. Creio tipo nas forças cósmicas. Que sou uma formiga no meio do nada, mas que, ao mesmo tempo, eu sou tudo, porque vivo para mim acima de tudo. E é mesmo assim. É no que eu creio acima de tudo. (Estudante universitário, sexo masculino, 20 anos)

Eu acho que não há sociedades ideais. (...) Eu não tenho nenhuma fórmula mágica, nem a quero ter, percebes? Eu sou mais uma dessas pessoas que andam aí. (...) Não sou nada! Sou mais uma gotinha, que está aqui dentro da minha casa e da minha vida, face à minha sociedade! (...) Por isso é que eu, no meu dia-a-dia, tento fazer o melhor possível da minha vida, p'a viver feliz a minha vida, e não pensar nisto tudo, não é? Quando pago os impostos e essas coisas ao Estado, logo penso neles. Pá, agora na minha vida e na minha família, pá, tento levar o melhor possível, e fazer as coisas à minha maneira, para não ter que sofrer, não é? (...) É cada um nas suas próprias casas. Epá, ou na sua família, ou na sua vida, há que se proteger e tentar viver o mais pacificamente. (...) E não é com peace and love que vamos conseguir mudar as coisas! Não é com guerras, mas também não é com peace and love, não é? Epá, pronto, e acho que se os hippies dos anos 60 vivessem agora, morriam todos sidosos. Sinceramente, é a ideia que eu tenho deles, 
sinceramente (risos). (Gerente de estúdio de tatuagem e body piercing, 9. ${ }^{\circ}$ ano de escolaridade, sexo feminino, 39 anos)

Longe do militantismo colectivista e programático que caracterizava alguns dos movimentos juvenis contestatários dos anos 70 e 80 - chega-se a ironizar a acção social destes movimentos culturais, como os movimentos hippie e punk-, estes jovens não pretendem mais do que marcar performativamente a sua distância pessoal perante o ordenamento social e político que percepcionam na sociedade moderna, e nele demarcar um espaço alternativo de existência social. Esta forma de (re)acção social é empreendida já não num sentido idealista e holista, orientada por elaborados sistemas ideológicos em função do "bem comum", mas no sentido pragmático e microscópico de, tão-somente, mudar o mundo de vida do agente, esse "sector do mundo quotidiano que está ao seu alcance e que, do seu ponto de vista, se ordena espacial e temporalmente em volta de si, como centro" (Pais 2002: 89). ${ }^{21}$

Descrentes da possibilidade de transformar o Mundo, estes jovens requerem, sim, liberdade e espaço de acção para transformar a sua existência, a sua vida e, no âmbito desta, o corpo de que se sentem proprietários. Ou, como coloca Ortega, "não podendo mudar o mundo, tentamos mudar o corpo, o único espaço que restou à utopia, à criação. As utopias corporais substituem as utopias sociais" (Ortega 2004: 252). Marcar extensivamente o corpo é, portanto, uma forma de resistência que se mobiliza com propósitos mais individualistas, que pretende a construção pessoal e reivindicação social de um espaço autónomo e emancipado de subjectividade, gesto que simboliza a aspiração do jovem à conquista de um absoluto sentido de individualidade, autenticidade e liberdade de acção.

Daí a reivindicação dos seus cultores por uma cultura moral ${ }^{22}$ que privilegie direitos culturais particularistas, regida por valores de liberdade e respeito pelas expressões voluntárias e distintivas de individualidade, princípios orientadores da estratégia de remoralização da vida quotidiana característica da sua reflexividade transformadora. Uma cultura moral, portanto, no âmbito da qual a acção de modificação do corpo seja isenta não apenas dos constrangimentos normativos que tendem à sua padronização sob a égide de uma imagem conformada do "corpo jovem", como também livre das sanções sociais a que se vêem sujeitos diariamente, em função da condição culturalmente marginal dos

21 Em contraste com a zona das coisas distantes (Mead 1963 [1933]; Blumer 1969), o mundo de vida corresponde ao mundo de alcance efectivo do indivíduo, à sua zona de operação quotidiana (Schutz e Luckmann 1977: 54-55), organizada «em torno do 'aqui' do meu corpo e do 'agora' do meu presente. Este 'aqui e agora' é o foco da atenção que presto à realidade da vida quotidiana" (Luckmann e Berger 1999 [1966]: 39-40).

22 Para empregar o termo de Lalive d'Epinay (1992), que o define enquanto sistema de crenças, significados e valores orientadores de modos de vida e comportamentos individuais. 
estilos de vida que manifestam e que encontram no corpo e nos visuais o seu suporte expressivo. Mais do que uma atitude de relativismo cultural, as reivindicações destes jovens apontam, claramente, para uma ética de pluralismo coexistencial, no sentido de ver instituída uma "desordem da moral expressa na existência de múltiplas moralidades, frequentemente conflituantes entre si" (Pais 2004: 14).

[Sou] Anarquista! Se quiseres... Não anárquico, anarquista. Anarquista, e isto é a minha própria explicação, não é baseada nem em filósofos, nem pensadores. Anarquista é quando se pretende promover a filosofia. Anárquico é quando pretende promover a acção em si. Ou seja, as minhas letras não têm como objectivo incentivar as massas à destruição da ordem imposta, mas sim fazê-las pensar pela cabeça delas. (...) Livre de preconceitos, livre de tabus. Livre de barreiras. (...) Neste momento dou-me com gente mais nova, como com gente mais velha, com gente de várias correntes literárias, de várias correntes filosóficas, de várias correntes de pensamento. E nunca segreguei ninguém porque é isto ou porque é aquilo, ou porque tem aspirações a ser ou porque já deixou de ser isto ou aquilo. Nem em termos de escolhas sexuais eu faço discriminações. Tenho amigos e amigas com as mais variadas cores e com os mais variados feitios. Não aborreço ninguém. Desde que não se metam... Lá está, o grande princípio da anarquia é “a minha liberdade acaba onde começa a liberdade do outro" e vice-versa. A partir do momento em que não comecem a querer interferir com o meu mundo, eu respeito o mundo dos outros. Abarco no meu mundo todos aqueles que eu acho que devem participar dele. Quando alguém começa a forçar a entrada, eu sou o primeiro a mandá-lo para trás. (Profissional de body piercing, frequência universitária, sexo masculino, 25 anos)

E eu virei um bocado para objectivos um bocado anarquistas, mas aquela anarquia... utópica, de, pá, eu respeito os outros, respeitem-me a mim. Porque se não, se não me respeitarem a mim, se me pisam os pezinhos, está tudo lixado! (...) Eu não ligo à política. Eu tento respeitar os outros e tento que os outros me respeitem. (...) [Mas lês obras anarquistas, coisas assim?] Não. Pá, partilho só o pensamento naquela base de respeito, mais nada. Aliás, eu política, futebol, religião, é meter tudo num saco, porque normalmente as pessoas que falam sobre isso são fanáticos e provocam discussão. Porquê? Porque não respeitam a opinião. (...) [valores fundamentais] Respeito. Pá, lá está, a questão das guerras, imagina só: uma pessoa que me pise os dedos, ou seja, que me faça alguma coisa de mal, pá, só se eu tiver muito bem disposta é que não vou pisar os deles, não é, porquê? - porque pisou-me, é o meu espaço, é a minha pessoa. Agora, por ideais de conjunto, não ligo assim tanto. Agora, individualmente ligo um bocado mais, porque... Quer dizer, 
porra! A vida é só uma, é a minha vida, e vão-me estar aqui a dizer "não faças"?! (Profissional de body piercing, estudante universitária, sexo feminino, 27 anos)

É nesta perspectiva que podemos olhar para os regimes de marcação extensiva do corpo como expressão do que Giddens designa de política de vida, uma política que "não diz respeito primariamente às condições que nos libertam de modo a fazermos opções: ela é uma política da opção, da escolha" (Giddens 1997 [1991]: 198), consubstanciada com fins e meios que visam alargar as condições de exercício das decisões de vida, que pretende conquistar não poder político na sua esfera de exercício tradicional, mas espaço social de manobra para novas formas de protagonismo que permitam a auto-realização identitária e a possibilidade de formular projectos pessoais de estilo de vida que integrem coerente e reflexivamente experiências passadas e circunstâncias externas.

\section{CONSIDERAÇÕES FINAIS}

A mobilização da tatuagem e do body piercing em grande extensão corporal não denota, portanto, um projecto inteiramente "apolítico", como propõe Ortega (2004: 247). Ou um projecto de "pura estetização" (Mendes de Almeida 2000: 103), traduzido numa sucessão de gestos ornamentais, superficiais, frívolos, lúdicos e paródicos, de signos de consumo (Turner 1999). Por um lado, manifesta um processo de construção e emancipação social do jovem enquanto sujeito dotado de um espaço de exercício da sua subjectividade e da sua liberdade perante as formas de controlo e restrições estruturais a que vê sujeita a sua vida, fazendo recair sobre o seu próprio corpo a "elaboração e estilização de uma actividade no exercício do seu poder e na prática da sua liberdade" (Foucault 1979: 23). Por outro, embora se faça passar por um projecto ensimesmado, permanecendo firmemente entrincheirado numa política de vida que luta por um espaço de singularidade e liberdade individual, os jovens que o mobilizam ambicionam o reconhecimento social da sua política de vida, elegendo o corpo como terreno privilegiado de expressão e intervenção pública.

Ora, como propõe Gilberto Velho, "sendo [projectos] conscientes e potencialmente públicos, estão directamente ligados à organização social e aos processos de mudança social. Assim, implicando relações de poder, são sempre políticos. Sua eficácia dependerá do instrumental simbólico que puderem manipular, dos paradigmas a que estiverem associados, da capacidade de contaminação e difusão da linguagem que for utilizada, mais ou menos restrita, mais ou menos universalizante. Nem tudo nos projectos é político, mas, quando são capazes de aglutinar grupos de interesses, há que procurar entender sua riqueza simbólica e seu potencial de transformação" (Velho 1987 [1981]: 34). 
Afinal, se é no corpo que muitos jovens mais intensamente experimentam e vivem quotidianamente o controlo social e os respectivos mecanismos disciplinares e sancionadores, é também na superfície da pele que alguns encontram um "espaço liso" disponível à projecção, à celebração e à luta pela construção e reconhecimento de uma identidade imaginada como singular ("ser diferente"), autêntica ("ser eu próprio") e emancipada ("ser livre"), estendida num estilo de vida que se pretende escapatório às fórmulas estilísticas e itinerários sociais normativizados. Num sistema onde alguns jovens percebem a sua experiência social sujeita a constrangimentos e prescrições no sentido da massificação e homogeneização cultural, vêem na recriação e modificação permanente do seu corpo, através do uso extensivo da tatuagem e do body piercing, uma forma estilística de reacção que, através da dissidência, lhes permite assinalar esteticamente a sua presença individual no mundo e protagonizar performativamente uma forma de existência no mundo.

Deste modo, ao mesmo tempo que estes jovens vão construindo as suas identidades pessoais enquanto identidades somáticas ou bioidentidades (Ortega 2004), vão-se assumindo como "cidadãos em cujo corpo natural está em jogo o seu próprio ser político, (...) erguendo uma política do corpo que extravasa as categorias do discurso político clássico, repressivo ou emancipador, na medida em que não seguem um modelo de normalidade ou de correcção política, uma qualquer linha justa, para se construírem como modo ou estilo de vida, comunidade, identidade e cultura" (Cascais 2004: 48-52).

Já em Foucault encontrávamos uma abordagem do fenómeno político que o afastava do nível de análise do Estado e o localizava noutras esferas de acção social, fornecendo-nos alguns instrumentos conceptuais para a compreensão da intercepção da realidade corporal com o fenómeno político nas sociedades contemporâneas. Hoje, por sua vez, são inúmeros os autores que enfatizam a viragem cultural (Nash 2001) ocorrida na sociologia política e dos movimentos sociais, ao localizar diversos tipos de reivindicações e formas de activismo já não na esfera da política tradicional, mas na esfera da produção cultural e das identidades. A partir daqui, a acção política pode, potencialmente, existir e ser analisada enquanto tal em qualquer contexto da vida social em que o poder opere (sob a forma de resistência ou de subordinação), envolvendo a contestação de identidades e relações sociais normalizadas, nas quais um indivíduo ou grupo se veja subordinado a outro, seja em que zona social for.

A este processo Beck chama de reinvenção da política (2000), fazendo-o corresponder à re-politização de áreas e temas tradicionalmente fora das instâncias burocráticas e formais do exercício político e suas instituições representativas num contexto de modernização reflexiva. Maffesoli, por sua vez, designa esse mesmo processo de transfiguração do político (2002 [1992]), mostrando que equivale desta feita ao recente alargamento da paleta de formas e conteúdos políticos a práticas, causas e valores alternativos aos institucionalmente impostos, 
processo esse que vem acompanhado da transferência dos lugares tradicionais de exercício de cidadania e de participação social para os espaços intersticiais que pululam no actual contexto de neotribalização do mundo pós-moderno. Perante estes espaços há, efectivamente, a demonstração de um desejo de participação social por parte de alguns jovens, no sentido em que há uma vontade de partilha com os outros, de situações, eventos, interesses, e até dificuldades e problemas (de inserção, de profissionalização, de protecção, etc.).

Qualquer que seja a designação que tomam, são processos que dão conta da emergência de conflitos que radicam em estatutos e identidades que têm em comum, entre si, a especificidade de viver, voluntária ou involuntariamente, em zonas marginais e, por vezes, subterrâneas num mundo social cada vez mais fragmentado, a partir de onde os seus actores pretendem afirmar e construir subjectividades que procuram não ser reduzidas a categorias funcionais ou disfuncionais do sistema, mas que, pelo contrário, buscam o respeito, reconhecimento e a dignificação social da sua diferença cultural e/ou pessoal específica.

A crítica imanente à vida social (nas suas ordens societal, económica e cultural) de que são agentes produtores e reprodutores e que vem fundamentar a sua acção social e os laços sociais que eventualmente os venham a unir, já não repousa sobre "imperativos categóricos" que procuram a igualdade no universalismo, mas sobre "imperativos atmosféricos", de ordem particularista e relativista (Maffesoli 2002 [1992]: 16-17). Quer isto dizer que a recusa do estatuto de identidade subordinada e o desenvolvimento de estilos de vida e configurações de relações sociais mais igualitários, prefiguram-se equacionados não no quadro tradicional e universalista de cidadania, que pressupõe o mesmo conjunto de liberdades e responsabilidades cívicas para todos os cidadãos, mas num quadro de diversidade social, cultural e ética que implica um modelo de sociedade mais pluralista, recusando os entendimentos dominantes e normativos sobre a vida em sociedade que categorizam o comportamento individual dentro de um código exclusivo de valores e virtudes públicas, e recolocando-os como possibilidade entre tantas outras.

Estes jovens pretendem fazer reconhecer o corpo marcado como uma possibilidade de corporeidade entre outras possíveis, em conjunto com outras estéticas e decisões estilísticas. Trata-se de uma postura estética que traz consigo uma postura ética homóloga, tentado abrir caminho para a convivência na diferença (e não apenas com a diferença) e para o respeito (e não apenas a tolerância). A luta pelo reconhecimento do seu espaço de subjectividade em condições de igualdade, respeito e dignificação do particularismo individual, é travada quotidianamente pelos jovens entrevistados no quadro de interacções que funda e densifica cada um dos seus "mundos de vida". Trata-se de um exercício de cidadania rasante, informal, socialmente microlocalizado, uma forma de cultura cívica que tem por objectivo a interpelação social através do 
culto do excesso, do extravagante, do bizarro, no sentido de "tomar a atitude do outro" na sua particularidade, que ambiciona uma remoralização cultural da vida quotidiana no sentido de promover estruturas de reciprocidade ou mutualidade intersubjectiva, de saber reconhecer e internalizar as perspectivas de outros generalizados.

Esta é, no dizer de Crossley, "a mais central das razões pelas quais a cidadania deve ser vista do ponto de vista do mundo de vida e da intersubjectividade" (2001: 37), para quem, a par de outros autores (Elliott 2001; Turner 1993, 2001; Stevenson 2001), há que alargar o universo de observáveis da cidadania para além da abordagem sistémica e holista que a tem caracterizado, bem como a respectiva análise para além da formalidade legal que a associa ao mero exercício de luta e reivindicação de conjunto de práticas legais e políticas.

A cidadania, enquanto conjunto de estratégias e recursos orientados no sentido da participação social efectiva e criativa é, actualmente, cada vez mais exercida e reivindicada na esfera cultural. E não apenas no plano da "luta pela democracia cultural" (Giroux 1992: 246) no sentido de diminuir os impactes do "capitalismo tardio" e do consequente crescimento massivo de identidades, actividades e artefactos nas esferas da produção cultural em sentido estrito (dos produtos das indústrias culturais ou provenientes do campo artístico), mas também de dar a conhecer e a fazer reconhecer todo um conjunto de questões associadas a determinadas imagens, representações, crenças e práticas sociais que são vistas como exclusivas e particulares de determinados "grupos".

É nesta perspectiva que a noção de cidadania tem visto recentemente alargada a sua esfera da acção e de reflexão, integrando não apenas as estratégias que visam a inclusão formal, mas também as lutas simbólicas e pouco visíveis pelo reconhecimento da mesma dignidade a formas e recursos culturais diferentes dos legítimos, pela desconstrução das noções de "normalidade" que constrangem a criatividade, pela garantia das mesmas condições de respeito e dignidade perante aqueles que a radicalizam enquanto forma de distintividade individual voluntariamente construída.

O valor social do corpo, por via da sua exposição no espaço público e social, enquanto lugar não apenas de classificação e discriminação, mas também meio privilegiado de expressão e recriação identitária, torna-o um dos mais populares recursos expressivos no âmbito destes novos activismos. Como? Através da subversão quer das normas e códigos corporais dominantes, quer das crenças e valores que, a partir do corpo e dos seus traços fenotípicos e/ou diacríticos, proporcionam o suporte ideológico para as construções hegemónicas de género, sexualidade, raça, classe, idade, etc. Subversão essa conseguida através da produção cultural de possibilidades e representações alternativas, criadoras de um mundo de diversidades que vem desmistificar e estilhaçar tais construções. 


\section{BIBLIOGRAFIA}

ABBOTT, Andrew, 1992, "What do cases do? Some notes on activity in sociological analysis", em Charles C. Ragin e Howard S. Becker, What is a case? Exploring the Foundations of Social Inquiry. Cambridge, Cambridge University Press, pp. 53-82.

BECK, Ulrich, 2000, "A reinvenção da política. Rumo a uma teoria da modernização reflexiva", em Ulrich Beck, Anthony Giddens e Scott Lash, Modernização Reflexiva. Política, Tradição e Estética no Mundo Moderno. Oeiras, Celta, pp. 1-51.

BENNETT, Andy, e K. Kahn-Harris (orgs.), 2004, After Subculture. Londres, Palgrave.

BENSON, Susan, 2000, "Inscriptions of the self: reflections on tattooing and piercing in contemporary Euro-America”, em Jane Caplan (ed.), Written on the Body: The Tattoo in European and American History. Princeton, Princeton University Press, pp. 234-254.

BerTAUX, Daniel, 1997, Les Récits de Vie. Paris, Nathan.

BERTHELOT, Jean-Michel, 1983, “Corps et société. Problèmes méthodologiques posés par une approche sociologique du corps”, Cahiers Internationaux de Sociologie, vol. LXXIV, pp. 119-131.

BLACKMAN, Shane, e Alan France, 2001, "Youth marginality under 'postmodernism”, em Nick Stevenson (org.), Culture and Citizenship. Londres, Sage, pp. 180-197.

BLACKMAN, Shane, 2005, "Youth subcultural theory: a critical engagement with the concept, its origins and politics, from the Chicago School to Postmodernism", Journal of Youth Studies, vol. 8, n. ${ }^{\circ}$ 1, pp. 1-20.

BLUMER, Herbert, 1969, Symbolic Interactionism. Perspective and Method. Nova Iorque, Prentice-Hall Englewood Cliffs.

BOLTANTSKY, Luc, 1975, "Les usages sociaux du corps", Annales - Économies, Sociétés, Civilisations, vol. 26, n. ${ }^{\circ} 1$, pp. 205-233.

BORRILLO, Daniel, 1994, "Estatuto y representacion del cuerpo humano en el sistema juridico”, Revista Española de Investigaciones Sociológicas, n. ${ }^{\circ}$ 68, pp. 21 1-222.

BOURDIEU, Pierre, 1998, "O conhecimento pelo corpo", Meditações Pascalianas. Oeiras, Celta, pp. 113-144.

_, 1977 , "Remarques provisoires sur la perception sociale du corps", Actes de la Recherche en Sciences Sociales, n. ${ }^{\circ}$ 14, pp. 51-54.

— 1968, Le Métier de Sociologue. Paris, Mouton.

BRITO, Roberto, 2002, "Identidades juveniles y praxis divergente: acerca de la conceptualización de la juventud”, em Alfredo Nateras Domínguez (ed.), Jóvenes, Cultura e Identidades Urbanas. México, Universidad Autónoma Metropolitana (UAM) y Miguel Ángel Porrúa, pp. 47-48.

CABral, Manuel Villaverde, 1997, Cidadania Política e Equidade Social em Portugal. Oeiras, Celta.

CANCLINI, Nestor Garcia, 1995, Consumidores e Cidadãos. São Paulo, Companhia das Letras.

CASCAIS, António Fernando, 2004, “Corpo, poder e desigualdade”, Manifesto, n. ${ }^{\circ}$ 5, pp. 36-55.

COLOGNESE, Sílvio, e José Luiz Bica de Melo, 1998, "A técnica de entrevista na pesquisa social”, Cadernos de Sociologia, n. ${ }^{\circ}$ 9, pp. 143-159.

CROSSLEY, Nick, 2001, "Citizenship, intersubjectivity and the lifeworld", em Nick Stevenson (ed.), Culture and Citizenship. Londres, Sage, pp. 33-46. 
CROSSLEY, Nick, 1997, "Corporeality and communicative action: embodying the renewal of critical theory", Body \& Society, vol. 3, n. ${ }^{\circ}$ 1, pp. 17-46.

CRUZ, Rossana Reguillo, 2002, "Cuerpos juveniles, políticas de identidade”, em Carles Feixa, Didel Molina e Carles Alsinet (eds.), Movimientos Juveniles en América Latina. Pachucos, Malandros, Punketas. Barcelona, Ariel, pp. 151-165.

CUNHA, Manuela, 1996, "Corpo recluído. Controlo e resistência numa prisão feminina", em Miguel Vale de Almeida (ed.), Corpo Presente. Treze Reflexões Antropológicas sobre o Corpo. Oeiras, Celta Editora, pp. 72-86.

D'EPINAY, Lalive, 1992, "Beyond the anatomy: work versus leisure? The process of cultural mutation in industrial societies during the twentieth century", International Sociology, vol. 7 , n. ${ }^{\circ} 4$, pp. 379-412.

DELEUZE, Gilles, 1980, Mille Plateaux. Paris, Minuit.

DEMELLO, Margo, 1993, “The Convict Body: tattooing among male American prisoners", Anthropology Today, vol. 9, n. ${ }^{\circ}$ 6, pp. 10-13.

DRULHE, Marcel, 1987, “L'incorporation”, Sociétés, n. ${ }^{\circ}$ 15, pp. 5-6.

ELLIOTT, Anthony, 2001, “The reinvention of citizenship”, em Nick Stevenson (ed.), Culture and Citizenship. Londres, Sage, pp. 47-61.

FEIXA, Carles, 1998, De Jóvenes, Bandas y Tribus. Barcelona, Ariel.

FERreIRA, Vítor Sérgio, 2006a, Marcas que Demarcam. Corpo, Tatuagem e Body Piercing em Contextos Juvenis, tese de doutoramento, Lisboa, ISCTE.

— 2006 b, "Corpo, trabalho e estilo de vida: a concretização de um projecto identitário entre os profissionais da tatuagem e bodypiercing", em Adolescência(s): Percurso(s) de um Tempo Inventado. Lisboa, Casa Pia de Lisboa, Divisão de Educação e Ensino e Acção Social.

— 2004 a, "Do renascimento das marcas corporais em contextos de neotribalismo juvenil”, em José Machado Pais e Leila Maria da Silva Blass (eds.), Tribos Urbanas: Produção Artística e Identidades. São Paulo, Annablume.

— $2004 b$, "A expressão estética das marcas corporais em contextos de neotribalismo juvenil", em José Machado Pais e Leila Maria da Silva Blass (eds.), Tribos Urbanas: Produção Artística e Identidades. Lisboa, Imprensa de Ciências Sociais.

— OBS, n. ${ }^{\circ} 13$.

— 2003, "Atitudes dos jovens portugueses perante o corpo", em José Machado Pais e Manuel Villaverde Cabral (eds.), Condutas de Risco, Práticas Culturais e Atitudes perante o Corpo. Oeiras, Celta Editora, pp. 265-366.

FONTENAY, Elisabeth, 1972, “Corps et biens. Notes sur le corps propre et la propriété privée”, Tropique, Revue Freudienne, n. ${ }^{\circ}$ 9-10, pp. 109-138.

FOUCAUlT, Michel, 1999 [1975], Vigiar e Punir. História da Violência nas Prisões. Petrópolis, Editora Vozes.

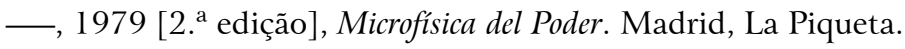

FRIEDMAN, Monroe, 1999, Consumer Boycotts: Effecting Change Through the Marketplace and the Media. Londres, Routledge.

GHIGLIONE, Rodolphe, e Benjamin Matalon, 1978, Les Enquêtes Sociologiques - Théories et Pratique. Paris, Armand Colin.

GIDDENS, Anthony, 1997 [1991], Modernidade e Identidade Pessoal. Oeiras, Celta Editora. GIROUX, Henry A., 1992, Border Crossings. Londres, Routledge. 
GLASER, Barney, e Anselm L. Strauss, 1967, The Discovery of Grounded Theory: Strategies for Qualitative Research. Chicago, Aldine Publishing Company.

HARDIN, Michael, 1999, "Ma(r)king the objected body: a reading of contemporary female tattooing”, Fashion Theory, vol. 3, n. ${ }^{\circ}$ 1, pp. 81-108.

HARPER, Douglas, 1992, "Small N's and community case studies", em Charles C. Ragin e Howard S. Becker, What is a case? Exploring the Foundations of Social Inquiry. Cambridge, Cambridge University Press, pp. 139-158.

HEBDIGE, Dick, 1988, Hiding in the Light. On Images and Things. Londres, Routledge.

—, 1986 [1979], Subculture. The Meaning of Style. Londres, Methuen.

HESMONDHALGH, David, 2005, "Subcultures, scenes or tribes? None of the above", Journal of Youth Studies, vol. 8, n. ${ }^{\circ}$ 1, pp. 21-40.

HIERNAUX, Jean-Pierre, 1997 [1995], "Análise estrutural de conteúdos e modelos culturais: aplicação a materiais volumosos”, em AA.VV., Práticas e Métodos de Investigação em Ciências Sociais. Lisboa, Gradiva, pp. 156-202.

HIRSCHMAN, Albert O., 1970, Exit, Voice and Loyalty: Responses to Decline in Firms, Organizations and States. Cambridge, MA, Harvard University Press.

KENT, David, 1997, “Decorative bodies: the significance of convicts' tattoos", Journal of Australian Studies, n. ${ }^{\circ}$ 53, pp. 78-88.

LAÉ, Jean-François, e Bruno Proth, 2002, "Les territoires de l'intimité, protection et sanction”, Ethnologie Française, vol. 32, n. ${ }^{\circ}$ 1, pp. 5-10.

LALANDA, Piedade, 1998, "Sobre a metodologia qualitativa na pesquisa sociológica", Análise Social, vol. 33, n. ${ }^{\circ}$, pp. $871-883$.

LIEBERSON, Stanley, 1992, "Small N's and big conclusions: an examination of the reasoning in comparative studies based on a small number of cases", em Charles C. Ragin e Howard S. Becker, What is a case? Exploring the Foundations of Social Inquiry. Cambridge, Cambridge University Press, pp. 105-118.

LOPES, João Teixeira, 2002, "Razão, corpo e sentimento na teoria social contemporânea", Sociologia, n. ${ }^{\circ}$ 12, pp. 57-64.

LUCKMANN, Thomas, e Peter Berger, 1999 [1966], A Construção Social da Realidade. Tratado de Sociologia do Conhecimento. Lisboa, Dina Livro.

MAFFESOLI, Michel, 2002 [1992], La Transfiguration du Politique. La Tribalisation du Monde Postmoderne. Paris, La Table Moderne.

MAGAlHães, Pedro, 2004, "Democratas, descontentes e desafectos: as atitudes dos portugueses em relação ao sistema político", em André Freire, Marina Costa Lobo e Pedro Magalhães (eds.), Portugal a Votos. As Eleições Legislativas de 2002. Lisboa, Imprensa de Ciências Sociais, pp. 333-361.

MAROY, Christian, 1997 [1995], "A análise qualitativa de entrevistas”, em AA.VV., Práticas e Métodos de Investigação em Ciências Sociais. Lisboa, Gradiva, pp. 117-155.

McDONALD, Kevin, 2004, "Oneself as another: from social movement to experimence movement”, Current Sociology, vol. 52, n. ${ }^{\circ} 4$, pp. 575-593.

—, 2002 , "From solidarity to fluidarity: social movements beyond 'colective identity' - the case of globalization conflicts”, Social Movement Studies, vol. 1, n. 2 2, pp. 109-128.

—, 1999, Struggles for Subjectivity: Identity, Action and Youth Experience. Cambridge, Cambridge University Press.

McKAY, George, 1996, Senseless Acts of Beauty. Cultures of Resistance Since the Sixties. Londres, Verso. MEAD, George-Herbert, 1963 [1933], L’Esprit, Le Soi, La Société. Paris, PUF. 
MENDES DE ALMEIDA, Maria Isabel, 2000, "Nada além da epiderme: a performance romântica da tatuagem", Psicologia Clínica, vol. 12, n. ${ }^{\circ}$ 2, pp. 100-147.

MUGGLETON, David, e Rupert Weinzierl, 2003 (orgs.), The Post-Subcultures Reader. Oxford, Berg.

MUGGLetON, David, 2002 [2000], Inside Subculture. The Postmodern Meaning of Style. Oxford, Berg.

NASH, Kate, 2001, "The 'cultural turn' in social theory: towards a theory of cultural politics”, Sociology, vol. 35, n. ${ }^{\circ}$ 1, pp. 77-92.

ORLIE, Melissa A., 2002, “The desire for freedom and the consumption of politics", Philosophy \& Social Criticism, vol. 28, n. ${ }^{\circ} 4$, pp. 395-417.

ORTEGA, Francisco, 2004, "Modificações corporais e bioidentidades", Revista de Comunicação e Linguagens, n. ${ }^{\circ} 33$, pp. 247-263.

PAIS, José Machado, 2004, "Quotidiano e reflexividade”, Actas do V Congresso Português de Sociologia, organizado pela Associação Portuguesa de Sociologia e realizado na Universidade do Minho, sob o tema "Sociedades Contemporâneas: Reflexividade e Acção".

—, 2002, Sociologia da Vida Quotidiana. Lisboa, Imprensa de Ciências Sociais.

—_, 2001, Ganchos, Tachos e Biscates. Jovens, Trabalho e Futuro. Porto, Âmbar.

—_, 1998, "Introdução", em José Machado Pais (ed.), Gerações e Valores na Sociedade Portuguesa Contemporânea. Lisboa, Secretaria de Estado da Juventude/Instituto de Ciências Sociais, pp.17-58.

—_, 1993, Culturas Juvenis. Lisboa, Imprensa Nacional/Casa da Moeda.

PAYNE, Geoff, e Malcolm Williams, 2005, "Generalization in qualitative research", Sociology, vol. 39, n. 2 , pp. 295-314.

PEIXOTO, Rocha, 1990, "A tatuagem em Portugal”, Etnografia Portuguesa. Lisboa, Publicações Dom Quixote.

PITTS, Victoria, 2003, In the Flesh: The Cultural Politic of Body Modification. Nova Iorque, Palgrave Macmillan.

POLHEMUS, Ted, e J. Benthall (eds.), 1975, The Body as a Medium of Expression. Londres, Allen Lane.

RABY, Rebecca, 2005, “What is resistance?”, Journal of Youth Studies, vol. 8, n. ${ }^{\circ}$ 1, pp. 151 $-171$.

RADLEY, Alan, 1998, “Displays and fragments. Embodiment and the configuration of social worlds", em Henderikus J. Stam (ed.), The Body and Psychology. Londres, Sage, pp. 13$-29$.

RICHARDS, David, 2001, “Is my Body my Property?”, Social Research, vol. 68, n. ${ }^{\circ}$ 1, pp. 83-101.

ROCHA, M. A. Tavares, 1985, "Antropologia criminal", em Cem Anos de Antropologia em Coimbra 1885-1985. Coimbra, Museu e Laboratório Antropológico.

RUCHT, Dieter, 1990, “The strategies and action repertoires of new movements", em Dalton Russel e Manfred Kuechler (eds.), Challenging the Political Order: New Social and Political Movements in Western Democraties. Cambridge, Polity Press, pp. 156-173.

RUQUOY, Danielle, 1997 [1995], "Situação de entrevista e estratégia do entrevistador", em AA.VV., Práticas e Métodos de Investigação em Ciências Sociais. Lisboa, Gradiva, pp. 84-116. 
SCHRADER, Abby M., 2000, "Branding the other/tattooing the self. Bodily inscription among convicts in Russia and the Soviet Union”, em Jane Caplan (ed.), Written on the Body: the Tattoo in European and American History. Princeton, Princeton University Press, pp 174-192.

SCHUTZ, Alfred, e Thomas Luckmann, 1977, Las Estructuras del Mundo de la Vida. Buenos Aires, Amorrortu.

SENNETT, Richard, 1998, The Corrosion of Character. The Personal Consequences of Work in the New Capitalism. Nova Iorque/Londres, W. W. Norton \& Company.

STEVENSON, Nick (ed.), 2001, Culture and Citizenship. Londres, Sage, pp. 1-10.

STEWARD, Samuel M., 1990, Bad Boys and Tough Tattoos. A Social History of the Tattoo with Gangs, Sailors, and Street Corner Punks 1950-1965. Nova Iorque, Haworth Press.

TOURAINE, Alain, 1995, "La formation du sujet», em François Dubet e Michel Wieviorka (eds.), Penser le Sujet. Autour d'Alain Touraine. Paris, Fayard, pp. 21-45.

TURNER, Bryan S., 2001, "Outline of a general theory of cultural citizenship", em Nick Stevenson (ed.), Culture and Citizenship. Londres, Sage, pp. 11-32.

— 1999, "The possibility of primitiveness: towards a sociology of body marks in cool societies”, Body \& Society, vol. 5, n. ${ }^{\circ} 2-3$, pp. 39-50.

—, (ed.), 1993, Citizenship and Social Theory. Londres, Sage Publications.

ULE, Mirjana, e Tanja Rener, 2001, “The deconstruction of youth”, em AA.VV., Transitions of Youth Citizenship in Europe: Culture, Subculture and Identity. Estrasbugo, Concelho da Europa, pp. $271-287$.

VALE DE ALMEIDA, Miguel, 2004, “O manifesto do corpo", Manifesto, n. ${ }^{\circ}$ 5, pp. 18-35.

VELHO, Gilberto, 1987 [1981], Individualismo e Cultura. Notas para uma Antropologia da Sociedade Contemporânea. Rio de Janeiro, Jorge Zahar Editor.

VEron, Elísio, [s/d], A Produção de Sentido. São Paulo, Cultrix.

Politics of the body, politics of life: tattoos and body piercing as a corporal expression of an ethics of dissidence - Vitor Sérgio Ferreira - Sociólogo, em pós-doutoramento no Instituto de Ciências Sociais da Universidade de Lisboa • vitor.ferreira@ics.ul.pt

The aesthetic of divergence that characterises extensively tattooed and body pierced bodies, represents a way of stylistic demarcation through which some young people build and reveal not only their personal identity, but also the way they perceive and relate to the world. It implies an aesthetic performance that embodies a homologous ethical attitude, consubstantiated in a sense of disaffiliation towards the established social and cultural order. It is an ethic of dissidence that reclaims a remoralisation of day-to-day life, so as to conquer a social space of existence in the world, where it is possible to live a commitment with a body, an identity, and a life style that aims to be "alternative" to the current "supermarket of styles" on offer, under conditions of authenticity, respect and personal freedom.

KEYWORDS: body, body marks, youth, life politics, cultural citizenship. 